\title{
A new conceptual model of coral biomineralisation: hypoxia as the physiological driver of skeletal extension
}

\author{
S. Wooldridge \\ Australian Institute of Marine Science, PMB 3, Townsville MC, QLD, 4810, Australia \\ Correspondence to: S. Wooldridge (s.wooldridge@aims.gov.au) \\ Received: 21 August 2012 - Published in Biogeosciences Discuss.: 18 September 2012 \\ Revised: 20 February 2013 - Accepted: 14 April 2013 - Published: 2 May 2013
}

\begin{abstract}
That corals skeletons are built of aragonite crystals with taxonomy-linked ultrastructure has been well understood since the 19th century. Yet, the way by which corals control this crystallization process remains an unsolved question. Here, I outline a new conceptual model of coral biomineralisation that endeavours to relate known skeletal features with homeostatic functions beyond traditional growth (structural) determinants. In particular, I propose that the dominant physiological driver of skeletal extension is night-time hypoxia, which is exacerbated by the respiratory oxygen demands of the coral's algal symbionts (=zooxanthellae). The model thus provides a new narrative to explain the high growth rate of symbiotic corals, by equating skeletal deposition with the "work-rate" of the coral host needed to maintain a stable and beneficial symbiosis. In this way, coral skeletons are interpreted as a continuous (long-run) recording unit of the stability and functioning of the coral-algae endosymbiosis. After providing supportive evidence for the model across multiple scales of observation, I use coral core data from the Great Barrier Reef (Australia) to highlight the disturbed nature of the symbiosis in recent decades, but suggest that its onset is consistent with a trajectory that has been followed since at least the start of the 1900s. In concluding, I outline how the proposed capacity of cnidarians (which includes modern reef corals) to overcome the metabolic limitation of hypoxia via skeletogenesis also provides a new hypothesis to explain the sudden appearance in the fossil record of calcified skeletons at the Precambrian-Cambrian transition - and the ensuing rapid appearance of most major animal phyla.
\end{abstract}

\section{Introduction}

“...the business of (coral reef organisms) is to stay alive until they have reproduced themselves, and the business of (coral reef biologists) is to try and understand how they do it. This understanding demands the recognition that structure and function are two indissociable aspects of (organism) organisation, linked in patterns that have been determined by the events in the remote past" (Barrington, 1979).

Shallow-water tropical reef ecosystems are the most prolific biomineralising ecosystems in nature with a calcification rate of about $2-6 \mathrm{~kg} \mathrm{CaCO}_{3} \mathrm{~m}^{-2} \mathrm{yr}^{-1}$ (Barnes and Devereux, 1984). The extensive accretion of $\mathrm{CaCO}_{3}$ skeletal material is testament to the evolutionary success of the symbiotic association between scleractinian ("reef-building") corals and dinoflagellate algae ("zooxanthellae") of the genus Symbiodinium (Stanley, 2006). Within this association, the zooxanthellae live within the coral tissues in extremely high densities (greater than $10^{6} \mathrm{~cm}^{-2}$ ) and perform intensive photosynthesis. Under the optimal conditions provided by warm, nutrient-poor tropical waters, the vast majority $(>90 \%)$ of this assimilated organic carbon ("photosynthate") is typically translocated to the coral, contributing substantially to its carbon and energy needs (reviewed by Yellowlees et al., 2008). Non-zooxanthellae corals do not accrete $\mathrm{CaCO}_{3}$ fast enough to build reef structures.

The high rate of calcification in symbiotic corals, both in terms of linear extension rates $\left(\mathrm{cm} \mathrm{yr}^{-1}\right)$ and calcification rate (the mass of $\mathrm{CaCO}_{3}$ deposited per unit time, $\mathrm{g} \mathrm{cm}^{-2} \mathrm{yr}^{-1}$ ), has traditionally been considered a diagnostic feature of the fitness of the symbiosis, i.e. the endpoint consequence of a stable and efficient functioning symbiosis. In this case, the zooxanthellae have been speculated to benefit 
host calcification via: (i) translocation of photosynthate to fuel active ion transport mechanisms and/or supply precursors required to synthesize the organic matrix that serves as the nucleating centre for $\mathrm{CaCO}_{3}$ crystals; (ii) the uptake of animal metabolic waste products that may interfere with $\mathrm{CaCO}_{3}$ precipitation, particularly phosphate that inhibit carbonate nucleation; and (iii) the increase in $\mathrm{CaCO}_{3}$ saturation by $\mathrm{CO}_{2}$ uptake and the maintenance of an oxygen environment (reviewed in Allemand et al., 2011).

An alternative viewpoint to explain the high calcification rate in symbiotic corals is that the very process of skeletogenesis is essential for the efficient functioning (and persistence) of the endosymbiosis, i.e. calcification represents the accumulation of re-purposed "waste" products arising from homeostatic functions performed by the host to maintain its own physiology, as well as the growth and photosynthetic activities of its algal partner. For example, (i) a proposed "trans" calcification mechanism identifies the process of $\mathrm{CaCO}_{3}$ deposition as a beneficial $\mathrm{CO}_{2}$-concentrating mechanism (CCM) leading to enhanced algal photosynthesis (McConnaughey and Whelan, 1997; Al-Horani et al., 2003), and (ii) a proposed "ureolytic" calcification mechanism identifies the process of $\mathrm{CaCO}_{3}$ deposition as an efficient waste nitrogen $\left(\mathrm{NH}_{4}^{+}\right)$recycling mechanism (Crossland and Barnes, 1974), which may be of particular relevance in the nutrient-depauperate environs of tropical reef ecosystems.

In this paper, I pursue further the idea that the rate of skeletal deposition is representative of the "work-rate" of the coral host needed to maintain a stable and beneficial symbiosis. In so doing, I build upon the earlier cases put forward for $\mathrm{CO}_{2}$ and $\mathrm{NH}_{4}^{+}$to propose an additional homeostatic driver, namely to compensate for oxygen $\left(\mathrm{O}_{2}\right)$ limitation of host respiration (metabolism), particular during nonphotosynthetic ("dark") conditions. In this respect, it is critically important to note that corals are oxygen conformers, and in symbiotic corals, the photosynthetic activity affects the $\mathrm{O}_{2}$ concentration in the host tissue (Rands et al., 1992; Kühl et al., 1995). When photosynthesis is active, $\mathrm{O}_{2}$ concentration in the coral tissue can reach $>250 \%$ of air saturation; whereby immediately following darkness, $\mathrm{O}_{2}$ may be depleted towards hypoxic conditions of $<2 \%$ of air saturation (Kühl et al., 1995). Recent results highlight that the process of host respiration is $\mathrm{O}_{2}$-limited in darkness (ColomboPallotta et al., 2010). Here, I outline the biological basis by which the host can compensate for this $\mathrm{O}_{2}$-limitation via fermentative (anaerobic) metabolism, and propose a direct linkage to the process of skeletal morphogenesis. The model predicts increased rates of skeletal extension when the fermentation process is activated during periods of enhanced dark respiration. The model also explains how fermentation (and linked skeletal extension) is stalled when the carbon reserves of the coral host needed to fuel the process are depleted during extended periods of metabolic stress.
In an effort to validate the new model, I introduce no new data sets instead relying on existing response data and cellular concepts to demonstrate the parsimonious predictions of the model across multiple scales of observation. I thus begin with a brief overview of the current understanding of the coral biomineralisation process, which has been extensively described by several excellent reviews (see e.g., Cohen and McConnaughey, 2003; Allemand et al., 2011). I then outline the biophysical and biochemical principles that underpin the new model and explain how they are commensurate with the prevailing evidence, including known variations in (i) the "vital effect" on oxygen and carbon stable isotope composition with taxonomy-linked ultrastructure, and (ii) the coral shape (i.e. morphological plasticity) of particular coral species in different environmental settings. In discussing the implications of the model, I provide a framework with which to interpret massive coral skeletons as a continuous (long-run) recording unit of the stability and functioning of the coral-algae endosymbiosis. This framework highlights the disturbed nature of the symbiosis in recent decades, but suggests that its onset is consistent with a trajectory that has been followed since (at least) the start of the 1900s. In concluding, I outline how the proposed capacity of cnidarians (which includes modern scleractinians) to overcome the metabolic limitation of hypoxia via the skeletogenesis process also provides a new hypothesis to explain the sudden appearance in the fossil record of calcified skeletons at the Precambrian-Cambrian transition - and the ensuing rapid appearance ("explosion") of most major animal phyla.

\section{Background: prevailing concepts in coral biomineralisation}

Coral growth or skeletogenesis is driven by calcification, the process whereby calcium $\left(\mathrm{Ca}^{+2}\right)$ and carbonate $\left(\mathrm{CO}_{3}^{-2}\right)$ ions obtained from seawater precipitate beneath the calcioblastic ectoderm (CE) of the coral polyp to form crystals of the calcium carbonate $\left(\mathrm{CaCO}_{3}\right)$ mineral polymorph, aragonite. Early workers considered coral skeleton formation as a purely physiochemical process, essentially an inorganic precipitation of aragonite fibres from a supersaturated solution (Bryan and Hill, 1941). More recent studies have increasingly emphasized the role of organic material - either as a structural organic matrix or as "seed" for crystal nucleation. Macro-molecules, such as acidic polysaccharides (Goreau, 1959; Goldberg, 2001) and proteins rich in acidic amino acids (Constantz and Weiner, 1988) are known to be embedded within the aragonitic skeletal components on a repeated (daily) sequence; constituting in the order of $1 \%$ by volume (Cohen and McConnaughey, 2003).

Although a vast literature exists for empirical aspects of coral calcification, the fundamental mechanisms and dynamics of skeletal morphogenesis are still, at best, only partially understood (reviewed by Cohen and McConnaughey, 2003; 


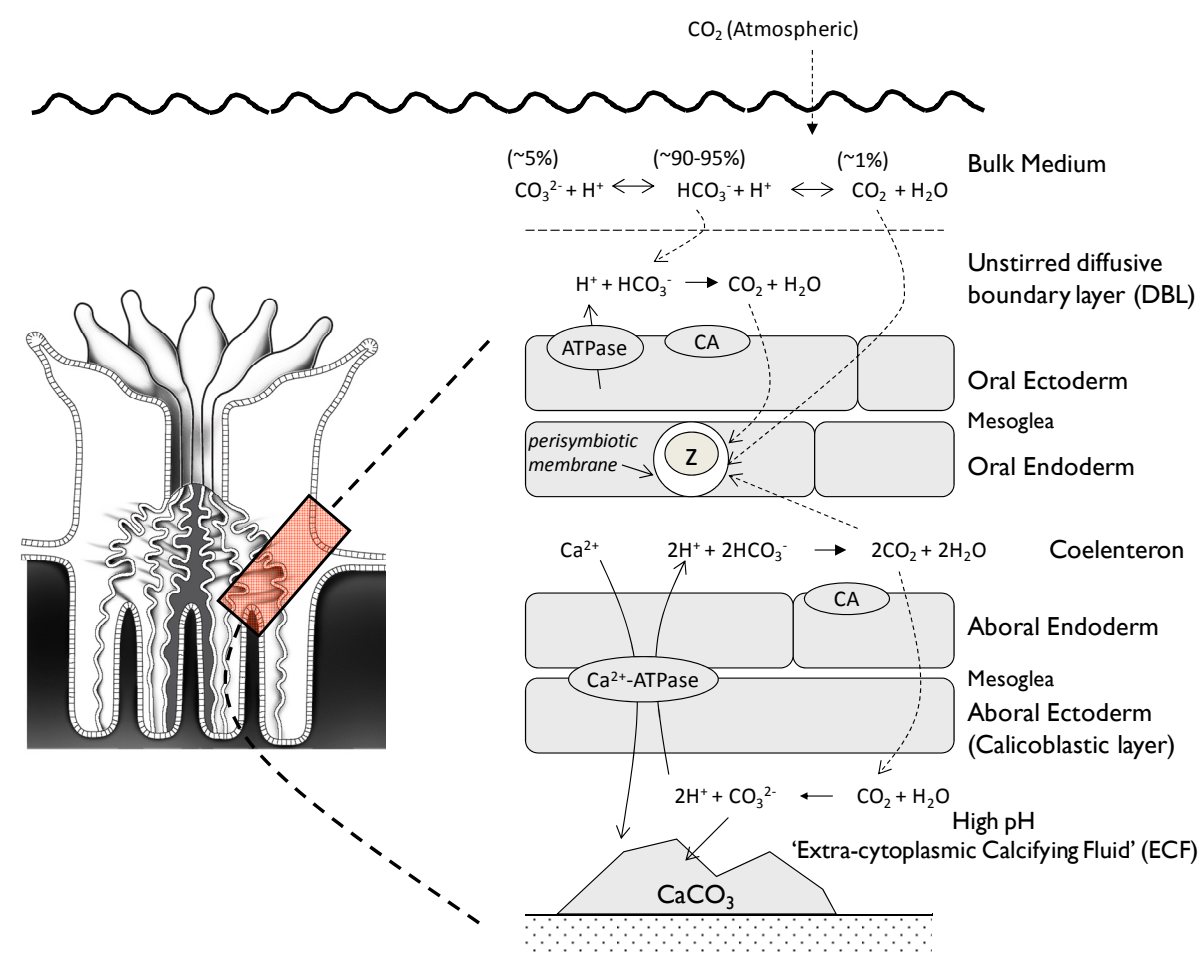

Fig. 1. Schematic of the "trans" calcification mechanism (after McConnaughey and Whelan, 1997), in which corals calcify by pumping protons $\left(\mathrm{H}^{+}\right)$from the calcifying fluid in exchange for $\mathrm{Ca}^{2+}$ ions from the coelenteron. This raises the $\mathrm{pH}$ of the precipitating microenvironment, generating high $\mathrm{CO}_{3}^{2-}$ concentrations and significantly increasing the saturation state of $\mathrm{CaCO}_{3}$. Protons discharged into the coelenteron react with bicarbonate liberating $\mathrm{CO}_{2}$ which is used for photosynthesis by the zooxanthallae $(Z)$.

Allemand et al., 2011). However, an increasingly common element to most model descriptions is the "trans" calcification mechanism (Fig. 1; McConnaughey and Whelan, 1997). Located at the basal membrane of the CE, the $\mathrm{Ca}^{2+}$-ATPase enzyme utilises metabolic energy (in the form of adenosine triphosphate, ATP) to actively exchange protons $\left(\mathrm{H}^{+}\right)$from the "extra-cytoplasmic calcifying fluid" (ECF) with $\mathrm{Ca}^{2+}$ ions from the seawater contained in the coelenteron. The physiochemical outcome of this ion exchange is twofold: (i) by elevating the $\left[\mathrm{Ca}^{2+}\right]$ and $\mathrm{pH}$ of the ECF, a higher aragonite saturation state $\left(\Omega_{\mathrm{arag}}\right)$ is achieved, thus promoting enhanced $\mathrm{CaCO}_{3}$ deposition rates, (ii) by transferring $\mathrm{H}^{+}$into the seawater contained by the coelenteron cavity, the carbonic anhydrase (CA) mediated dehydration of bicarbonate $\left(\mathrm{HCO}_{3}^{-}+\mathrm{H}^{+} \rightarrow \mathrm{CO}_{2}+\mathrm{H}_{2} \mathrm{O}\right)$ is facilitated, thereby increasing the potentially limiting supply of $\mathrm{CO}_{2(\mathrm{aq})}$ for endosymbiont photosynthesis. In this way, the biological functioning of the $\mathrm{Ca}^{2+}$-ATPase enzyme provides an indelible link between host calcification and zooxanthellae photosynthesis: autotrophic carbon products fuel the metabolic (respiratory) processes necessary to energise $\mathrm{Ca}^{2+}$-ATPase and promote $\mathrm{CaCO}_{3}$ deposition, which in turn enhances $\mathrm{CO}_{2}$-fixation and further transfer of photosynthate.

The physiochemical signature of the "trans" calcification process is well supported by actual measurements of $\mathrm{pH}$ and $\left[\mathrm{Ca}^{2+}\right]$ at the calcification site over a diurnal cycle (AlHorani et al., 2003). Indeed, substantial evidence exists to support a diurnal cycle in the skeletogenesis process during which the types of crystals deposited, their distribution about the skeletal surface, and the overall rate of $\mathrm{CaCO}_{3}$ deposition changes between day and night (reviewed by Cohen and McConnaughey, 2003). First, there is a distinct diurnal cycle in coral calcification rate, with rates 3-5 times higher recorded in daylight, correlated with a similar rhythm in the photosynthetic capacity of the zooxanthellae population (Chalker, 1976). Second, there are two different processes involved in calcification that are largely decoupled over the diurnal cycle: skeletal extension which is most rapid at night and skeletal thickening ("infilling") that is most rapid in daylight (Barnes and Crossland, 1980; Vago et al., 1997). The processes responsible for this apparent paradox were first revealed by Gladfelter $(1982,1983 a)$ who showed that the types of crystals accreted and their function in the skeleton-building process also follows a diurnal cycle. In this case, night-time calcification in the extending skeletal tips of Acropora cervicornis resulted in the accretion of randomly oriented granular crystals, which formed an extensive yet flimsy skeletal framework. The framework was filled in by the rapid growth of acicular (i.e. needle-like) crystal fibres during the day. 
Gladfelter's model of a night-time framework that causes the skeleton to vertically extend and daytime "infilling" that causes the skeleton to bulk up and thicken (attributed here to the $\mathrm{H}^{+}$pumping process associated with enhanced $\mathrm{Ca}^{2+}$-ATPase activity) has been substantiated for diurnal growth patterns in massive Porites skeletons (Fig. 2); including the distinct skeletal units arising during the "dark" and "light-enhanced" calcification periods (Fig. 3). The synchronous (cyclical) outworking of these two distinct calcification mechanisms fits with the traditional mineralogical description of skeletal fibre growth, in which fan-like systems of crystalline fibres radiate out from "centres of calcification" (COC) foci (Fig. 4; sensu Ogilvie, 1896; Barnes, 1970). However, it is now understood that crystal fibre growth (and consolidation) includes a "layered" morphology in which skeletal fibres with lengths of tens of micrometers consist of composite growth increments (bands) of aragonite approximately 2 to $5 \mu \mathrm{m}$ long separated by thin organic-rich layers (Cuif and Dauphin, 2005). The precise mechanism(s) leading to the "dark" calcification phase of skeletogenesis remain equivocal, but is believed to be mediated by the dynamic behaviour of the of the $\mathrm{CE}$, including: (i) the secretion of cellular products needed for the biological formation of a structural organic matrix (Johnston, 1980; Clode and Marshall, 2002) and (ii) the formation of small pockets of uplifted tissue into which the incipient skeletal framework extends (Barnes, 1970; Raz-Bahat et al., 2006).

\section{Formalising a linkage between respiratory hypoxia and "dark" calcification}

Aerobic respiration refers to the biological process by which organic carbon compounds (e.g., glucose) are mobilised and subsequently oxidised in a controlled manner. During respiration, free energy is released and incorporated into a form (ATP) that can be readily used for maintenance and growth. From a biochemical standpoint, aerobic respiration proceeds through three distinct stages: (1) glycolysis, (2) the tricarboxylic acid (TCA) cycle, and (3) an electron transport chain (so-called oxidative phosphorylation) that utilises oxygen $\left(\mathrm{O}_{2}\right)$ as the ultimate election acceptor (Fig. 5a). In glycolysis, glucose undergoes a limited amount of oxidation to produce pyruvate, a little ATP, and stored reducing power in the form of a reduced pyridine nucleotide, NADH. The TCA cycle and linked oxidative phosphorylation bring about the complete oxidation of pyruvate to $\mathrm{CO}_{2}$, and in so doing, generate a considerable amount of ATP. In total, glycolysis contributes less than $7 \%$ of the total ATP generated per molecule of glucose.

From an evolutionary standpoint, glycolysis is the oldest of the three stages of respiration. Unlike the TCA cycle and oxidative phosphorylation, no oxygen is required to convert glucose to pyruvate. However, $\mathrm{O}_{2}$-limitation of the TCA cycle and oxidative phosphorylation creates a problem for the

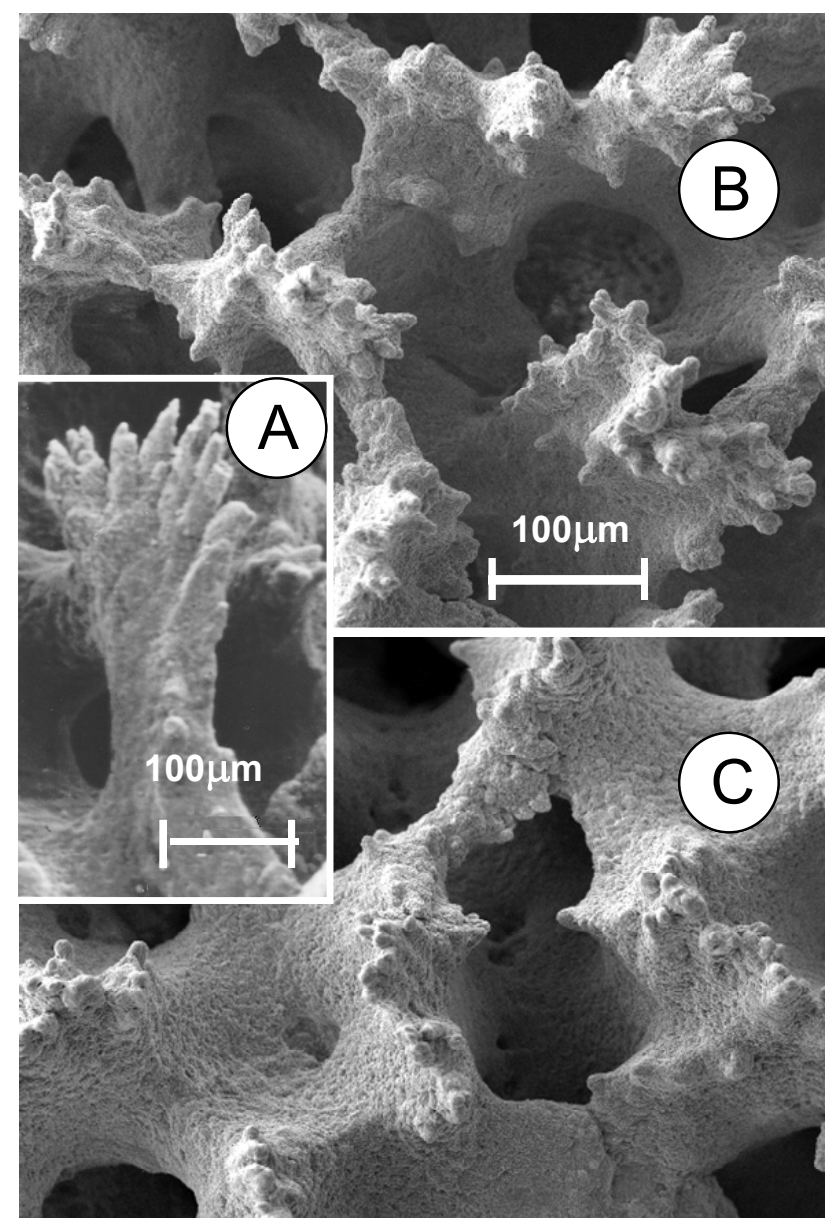

Fig. 2. (A) The tips of a growing septa of Porites lutea is covered in dentations, each consisting of an array of fine spines like fingers from a hand. (B) At night, calcification results in the elongation of the fingers by accretion of new calcification centers at the growing tips; thus the septal surface appears spiky. (C) During the day, the spaces between adjacent fingers are filled in by outward growth of aragonite fibre bundles. By the end of the day the surface of the septum has a smooth appearance. (Images courtesy of David Barnes, Australian Institute of Marine Science).

continued operation of glycolysis because the cells supply of $\mathrm{NAD}^{+}$is limited, and once the $\mathrm{NAD}^{+}$becomes tied up in the reduced state (NADH) the pyruvate dehydrogenase reaction is unable to take place. To overcome this problem, plants and other organisms can further metabolise pryruvate by carrying out fermentative metabolism; whereby two enzymes, pryruvate decarboxylase and alcohol dehydrogenase, act on pyruvate, ultimately producing ethanol (acetic acid) and $\mathrm{CO}_{2}$ and oxidising NADH in the process (Fig. 5b). Corals can survive $\mathrm{O}_{2}$-limitation for several days (Yonge et al., 1932), and are believed to use fermentation, as shown for other cnidarians (Ellington, 1977, 1980). Plants also utilise fermentation when oxygen levels are low - for example, in root tissue in flooded soils (Lu et al., 2005). 


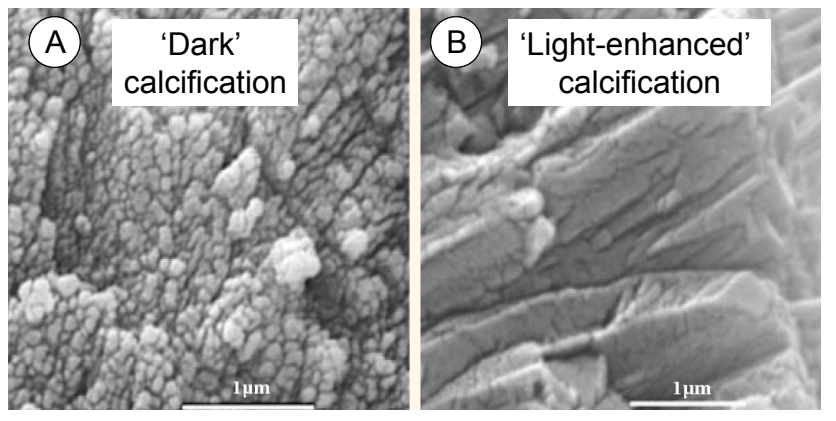

Fig. 3. Distinct skeletal units of Porites skeleton associated with "dark" and "light-enhanced" calcification phases. (A) At night, a new cluster of sub-micron granular (equant) crystals are deposited on the tips of pre-existing skeletal elements. (B) At daybreak, long, needle-shaped crystals grow from the "seed" crystals and are bundled into fan-shaped fascicule. (Images courtesy of Anne Cohen, Woods Hole Oceanographic Institution.)

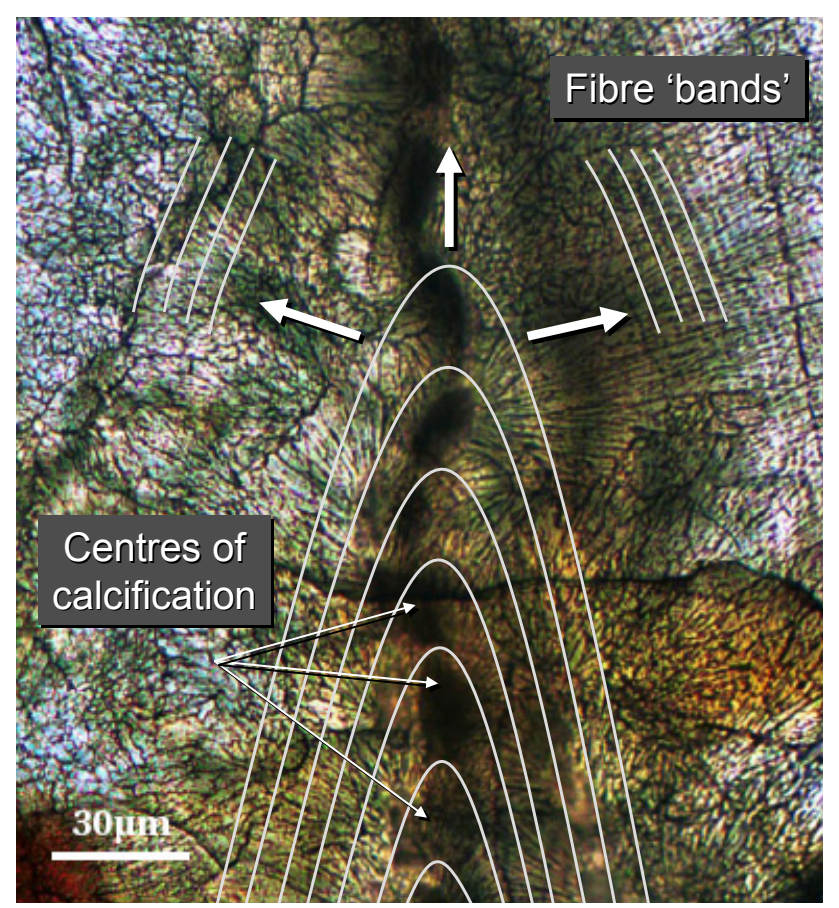

Fig. 4. Petrographic thin section of a Porites skeleton in the vertical extending region of a skeletal spine. The "centres of calcification" (COC) appears as a vertical line of discrete dark blobs. Their length $(\sim 30 \mu \mathrm{m})$ confirms that they are daily accretions. Bundles of needle-shaped fibres are seen to radiate out from each COC. The needle-shaped fibres consist of composite "daily" growth bands ( $\sim 2$ to $5 \mu \mathrm{m}$ ). (Image courtesy of Anne Cohen, Woods Hole Oceanographic Institution.)

With continuing oxygen deficiency, activation of ethanolic fermentation causes the cellular accumulation of acetate that eventually leads to pronounced intracellular acidification (Hochachka et al., 1973) and resultant (severe) cell dam-
(A)
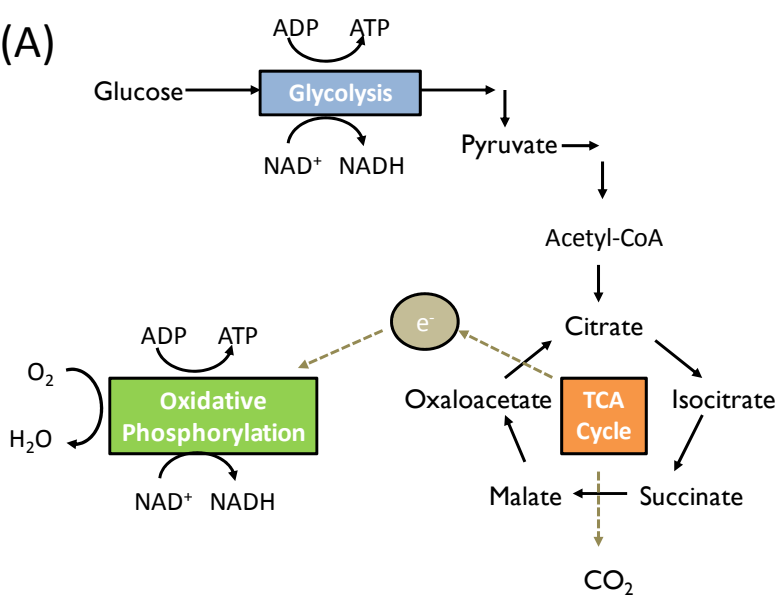

(B)
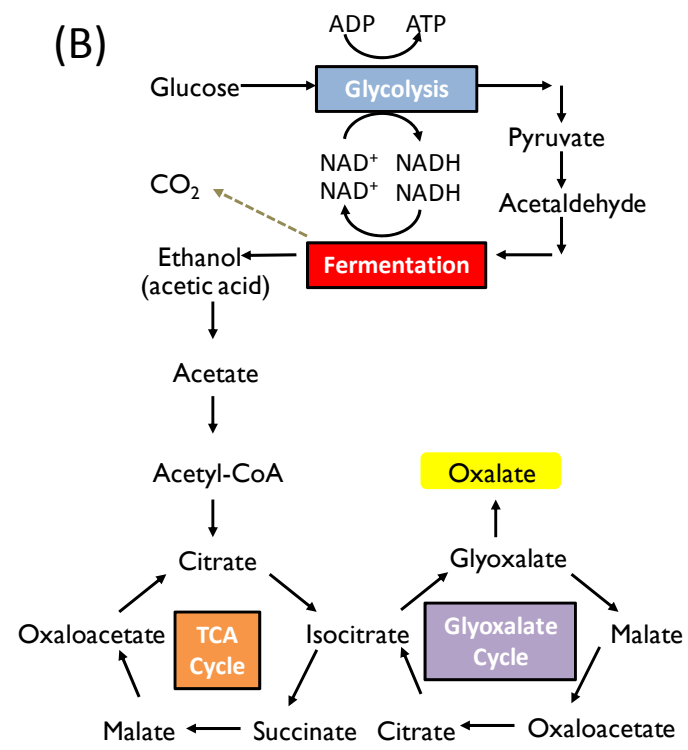

Fig. 5. (A) Conceptual representation of aerobic respiration, including glycolysis, the TCA cycle, and oxidative phosphorylation. Glucose is completely oxidised to $\mathrm{CO}_{2}$ while oxygen $\left(\mathrm{O}_{2}\right)$ serves as the ultimate electron acceptor, being reduced to water $\left(\mathrm{H}_{2} \mathrm{O}\right)$. (B) In the absence of $\mathrm{O}_{2}$, the TCA cycle and oxidative phosphorylation become stalled, but glycolysis can remain active so long as $\mathrm{NAD}^{+}$is continuously resupplied via anaerobic fermentation. The products of fermentation (e.g., acetate) must be metabolised to ensure they do not have a toxic effect upon cell physiology. Here, it is proposed that acetate is ultimately metabolised to oxalate via the operation of the glyoxylate cycle - a modification of the TCA cycle (after Lu et al., 2005).

age (Busa, 1986; Grieshaber et al., 1994). The response of flooded rice seedlings highlights a process that can alleviate the build-up of fermentation products, and thus ensure continued glycolysis. In this case, the rice seedlings couple fermentation with the glyoxylate cycle, which can metabolise acetate into acetyl-CoA under anaerobic conditions (Fig. 5b; $\mathrm{Lu}$ et al., 2005). The glyoxylate cycle is an ancient modification of the TCA cycle (Schnarrenberger and Martin, 2002; 
Kondrashov et al., 2006). Acetyl-coenzyme A synthetase catalyses the conversion of acetate into acetyl-CoA. The acetyl-CoA is metabolised in the glyoxylate cycle, bypassing the decarboxylation steps of the TCA cycle. The glyoxylate cycle occurs in bacteria, fungi and plants, but in very few animals; the notable exception being cnidarians (Kondrashov et al., 2006).

In plants, glyoxylate is an efficient precursor for oxalate production (Yu et al., 2010). Oxalate combines readily with calcium to form crystalline calcium oxalate $\left(\mathrm{CaC}_{2} \mathrm{H}_{2} \mathrm{O}_{4}\right)$ deposits. In terrestrial trees, calcium oxalate is often deposited within the annual growth ring structure of woody tissue, particularly during periods of stress (see e.g., Gourlay and Grime, 1994). In the marine environment, calcium oxalate contributes to the skeletogenesis process of red and green algae (Pueschel, 2000; Pueschel and West, 2007). The oxalate $\rightarrow$ calcium oxalate conversion can also occur unintentionally in humans; a reaction that underpins the deleterious formation of calcium oxalate deposits (so-called "kidney stones") within the urinary system. Extensive research on the formation of kidney stones highlights that the oxalate $\rightarrow$ calcium oxalate transition is enhanced by the presence of crystal binding substances, including hyaluronan (hyaluronic acid, HA) and osteopontin (OPN) (Asselman et al., 2003; Lamontagne et al., 2011). HA is a linear polysaccharide whose numerous charges along its length result in a complex interaction with cations, particularly $\mathrm{Ca}^{+2}$ (Gabriel and Carr, 1989). In water, HA easily aggregates into a coarse branching fibrillar (matrix) network (Hadler et al., 1982). OPN is a member of the aspartic acid-rich protein super family, which has a specific calcium crystal surface-adsorbing structure, and contains the Arg-Gly-Asp (RGD) sequence (Singh et al., 1993).

\subsection{A new conceptual model of coral biomineralisation}

Given cnidarians unique possession of the enzymes necessary for the glyoxylate cycle, I propose here a new model for "dark" coral calcification, whereby $\mathrm{O}_{2}$-limitation of aerobic respiration initiates a homeostatic host response that includes: (i) ethanolic fermentation - leading to the production of acetate, (ii) glyoxylate cycle metabolism - leading to the conversion of acetate into oxalate, and (iii) extracellular precipitation of calcium oxalate in the presence of oxalate, $\mathrm{Ca}^{2+}$ ions and crystal binding substances that form the fibrillar compartments of a reticular ("meshwork") matrix (Fig. 6a(i)).

The conceptual nature of the model means that many of the proposed linkages remain to be described and tested in their entirety; most notably relating to the dynamic functioning of the $\mathrm{CE}$ leading to the delivery of organic material at the skeletal-tissue interface, and the potential formation of small pockets of uplifted tissue into which the incipient skeletal framework extends. Efficient transport mechanisms can move vesiculated organic material through mesogleal canals (ducts) associated with the gastrovascular system of cnidarians (see e.g., Gateńo et al., 1998; Rodriguez-Lanetty et al., 2005). Indeed, the structural logistics of a vesicle-mesogleal transport mechanism that moves organic material to the site of calcification is entirely feasible, since the large intercellular spaces in which numerous vesicles reside (prior to their known release into the calcifying space) are in direct contact with the mesogloea (Clode and Marshall, 2002). Furthermore, during periods of vesicle release, mesogleal extensions containing numerous vesicles are observed to ramify into the intercellular space between the calicoblastic cell-layer (Isa, 1986; Le Tissier, 1988, 1991; Clode and Marshall 2002). The existence of a transport mechanism(s) would disregard any necessity for a direct spatial topology to exist between host tissue regions with highest $\mathrm{O}_{2}$-limitation and skeletal areas of maximum extension (e.g., distal tips and edges).

No calcium oxalate has ever been identified within the aragonitic skeletons of corals hence it is important to note that the proposed precipitation of calcium oxalate is not envisioned as a skeletal building block, but rather to act as a nucleating seed crystal that initiates skeletogenesis, i.e. aragonite $\left(\mathrm{CaCO}_{3}\right)$ crystal growth (Fig. 7). It is well established that the presence of a foreign substance can exert strong control over $\mathrm{CaCO}_{3}$ nucleation because interfacial energy between a crystal nucleus and a solid substrate is often lower than that of a crystal in contact with the solution (Mutaftschiev, 1993). Once the seed is initiated within the organic matrix structure, principles governing abiotic (i.e. inorganic) crystal growth in a supersaturated solution may prevail, with the initial crystal serving as a nucleation catalyst for formation of other crystals, and their epitaxial organisation into nearly parallel fishscale-shaped bundles (= fasciculi) (Barnes, 1970). Crystal fibres that happen to be oriented perpendicular to the skeletal surface (i.e. towards the CE) will extend the most rapidly and occlude those growing horizontally or at low angles. Fundamental to this idea, is that calcification occurs most rapidly in micron-sized spaces formed where the CE lifts away from the skeletal surface. The released organic products are eventually engulfed by mineral product which is limited in its extension by the CE tissue layer (Fig. 6a(ii)).

Major thickening (=epitaxial growth) of the aragonite needles of the fasciculi has previously been observed to occur during the "light-enhanced" period of calcification (Gladfelter, 1982, 1983a). As reviewed by Cohen and McConnaughey (2003), this thickening process is expected to benefit from the energy-dependent functioning of the $\mathrm{Ca}^{2+}$-ATPase enzyme. By substantially raising the aragonite saturation state of the precipitating microenvironment (ca. 25 = pH 9.28; Al-Horani et al., 2003), the "pumping" activity of $\mathrm{Ca}^{2+}$-ATPase aids the spontaneous deposition of $\mathrm{CaCO}_{3}$ upon all pre-existing skeletal elements in contact with the ECF (Fig. 6a(iii)).

The aragonite fibres of corals are commonly observed to have lengths of tens of micrometers (Fig. 3b). With the new 


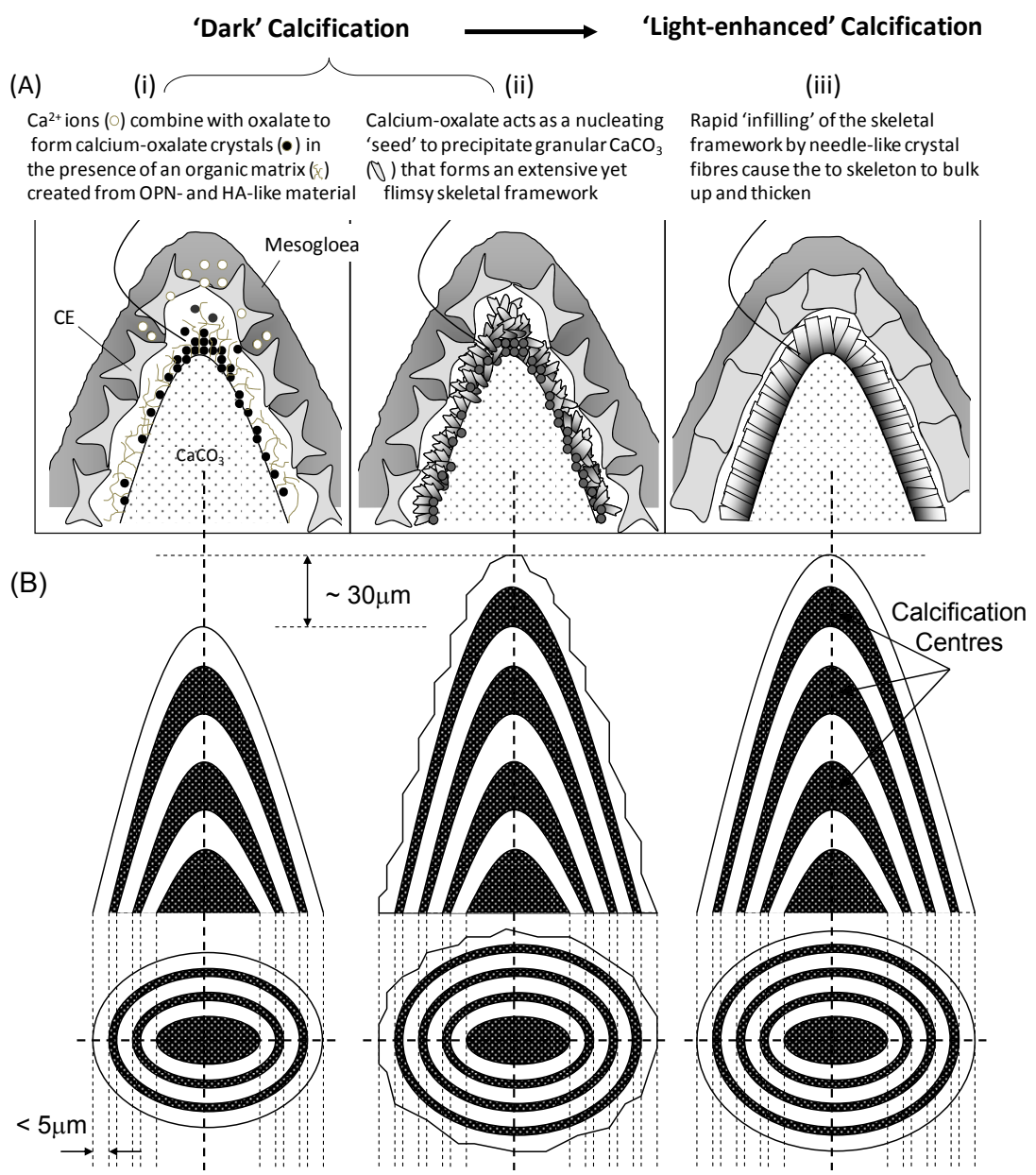

Fig. 6. Conceptual representation of the new biomineralisation model. (A(i)) During "dark" calcification the CE is biologically active, with the cells becoming highly interdigitated, thereby creating large intercellular spaces into which the mesoglea extends and ramifies (Johnston 1980). $\mathrm{Ca}^{2+}$ ions, oxalate, and calcium binding substances (e.g., HA and OPN) are secreted into the ECF by the cells of the CE (either directly or via the mesogloea) - weighted most heavily towards the tip region. The secretion mechanism(s) remains to be determined. The HA- and OPN-like substances act to form an organic matrix which helps to bind calcium-oxalate. (A(ii)) The calcium-oxalate crystals serve as a nucleating site for the formation of aragonitic $\mathrm{CaCO}_{3}$ crystals. (A(iii)) Major epitaxial growth of the aragonite fibres occurs during the "light-enhanced" period of calcification, which benefits from the energy-dependent functioning of the Ca ${ }^{2+}$-ATPase enzyme. During this period, the CE forms well-defined lateral cell borders with the mesogloea (Johnston, 1980). (B) With length scales of tens of micrometers, aragonite fibres grow as a superimposed succession of repeated organo-seed $\rightarrow$ inorganic crystal interactions across multiple diurnal $(24 \mathrm{~h})$ periods.

model description, the secondary nucleation of aragonite fibres upon crystal "seed" material is predicted to result in a horizontal fibre length of only $2-5 \mu \mathrm{m}$. Explanation for this apparent disparity in fibre length is provided by recent evidence showing that a coral fibre is not a single crystal of aragonite, but rather a composite structure built by superposition of micron-thick layers (Cuif and Dauphin, 2005). It can therefore be understood that with length scales of tens of micrometers, fibres actually represent the superimposed succession of several repeated seed $\rightarrow$ fibre interactions. By facilitating the spontaneous deposition of $\mathrm{CaCO}_{3}$ upon all preexisting skeletal elements in contact with the ECF, it is proposed that it is the supersaturating function of $\mathrm{Ca}^{2+}$-ATPase that facilitates this agglomeration process. Thus, for as long as the $\mathrm{CE}$ remains in contact with the accreting skeletal surface, thickening deposits are continually consolidated over all the skeletal elements (Barnes and Lough, 1993).

The notion of a repeated (i.e. cyclical) biomineralisation process aligns well the skeletal morphology revealed by chemical etching techniques, which display micrometer zonations or growth units (bands) in both longitudinal and transverse section (Stolarski, 2003; Cuif and Dauphin, 2005). Indeed, these growth bands are somewhat evident in Porites skeletons when viewed in thin section (sensu Fig. 4). For the new model description, such growth bands are suggested to correspond to the repeated organo-seed (= negative 
Step 1: $\mathrm{Ca}^{2+}$ ions from within the ECF combine with secreted oxalate to nucleate calcium-oxalate crystals; as controlled and promoted by the presence of an organic matrix created from OPN- and HA-like materials

Step 2: The bound $\mathrm{Ca}^{2+}$ ions attract $\mathrm{CO}_{3}{ }^{2-}$ ions (forming strong bonds that lower the required energy for nucleation), and by having a sufficient concentration of these ions, induce nascent $\mathrm{CaCO}_{3}$ nucleation

Step 3: Subsequent $\mathrm{CaCO}_{3}$ crystal growth can then proceed in a manner typical of abiotic $\mathrm{CaCO}_{3}$ precipitation from a supersaturated solution, with the initial crystal serving as a nucleation catalyst for the formation of other crystals

Note: The expected fast (ping-pong) dynamics of this multi-step process can be envisaged to form a template for epitaxial-type growth of the developing $\mathrm{CaCO}_{3}$ crystal fibres, wherein one crystal lattice overgrows (encrusts) another. For this reason, it is unlikely that calcium oxalate will be readily detected within the bulk aragonitic $\mathrm{CaCO}_{3}$ coral skeleton. In essence, the calcium oxalate behaves as an instantaneous (triggering) catalyst for $\mathrm{CaCO}_{3}$ deposition, but is subsequently engulfed and overgrown - for all intensive purposes lost from detection

Fig. 7. Proposed epitaxial growth sequence for $\mathrm{CaCO}_{3}$ crystal fibres.

etching) $\rightarrow$ fibre interactions; with a single etched couplet representative of a typical $24 \mathrm{~h}$ period. Figure $6 \mathrm{~b}$ provides an idealised representation (in both longitudinal and transverse section) of the proposed continuity of organo-mineral layers associated with the extending skeletal elements of the coral.

It is important to note that while the new coral biomineralisation model is described here in terms of zooxanthellate corals, there is little reason to suggest that the fundamental skeletogenesis drivers need differs significantly for nonzooxanthellae corals, or indeed other marine calcifying organisms, since the diffusive supply of oxygen is a constraint on (most-all) marine organisms (Denny, 1988; Pörtner, 2010). Also, even in the absence of photosynthetic symbionts, the metabolic cycling of non-zooxanthellate corals will be punctuated by a periodicity in $\mathrm{O}_{2}$-demand (and limitation) due to the entrained natural rhythms (e.g. circadian) that are known to exist in cnidarians (see e.g., Vize, 2009). Thus, the microstructure banding that exists within the aragonite fibres of deep-sea (non-zooxanthellae) corals (see e.g., Blamart et al., 2007) are entirely consistent with the expectations of the proposed model.

\subsection{Supporting evidence}

Central to evaluating the robustness of the new coral biomineralisation model is the need to demonstrate the involvement of hypoxia, anaerobic fermentation, glyoxylate, and calcium oxalate (and associated organic promoters) in the process of "dark" calcification. Future experiments are required to for- mally test this association. Here, I use the results of existing experiments to develop and initial weight-of-evidence.

Measurements confirm that corals experience hypoxia at night (Kühl et al., 1995; Colombo-Pallotta et al., 2010) and the proposed functioning of anaerobic fermentation and its link to skeletogenesis is consistent with the fact that "dark" calcification proceeds without the operation of the TCA cycle and linked oxidative transport chain (Chalker and Taylor, 1975). Also, the addition of glyoxylate to the extending tip region of the branching coral A. cervicornis has been shown to promote calcification at almost twice the rate of seawater alone, being even more beneficial than ATP (Crossland and Barnes, 1974). The fundamental importance of host enzymes to the "dark" calcification process is highlighted by the fact that chemical inhibitors of the protein synthesis needed for enzyme formation (e.g., emetine and cycloheximide) bring "dark" calcification to a halt without affecting algal photosynthesis (Allemand et al., 1998).

Direct support for the role of calcium oxalate as an initiating crystal seed material is more difficult to demonstrate as its proposed functioning means that it will be an effective "ghost" of the mineralised skeleton (Fig. 7). However, isotopic labelling and wash-out (efflux) experiments using ${ }^{45} \mathrm{Ca}$ do provide strong evidence for the presence of a small calcium compartment included within the bulk skeletal compartment (Tambutté et al., 1996). This skeletal compartment has a rapid half-time $(12.9 \mathrm{~min})$ compared to the bulk of skeleton $(167 \mathrm{~h})$ that is suggestive of a transient compartment, as would be predicted for the calcium oxalate seed material. The identification of organic material within the ECF that is known to stabilise and promote the precipitation of calcium oxalate (e.g., HA- and OPN-like substances) is also noteworthy. For example, (i) a hyaluronan-like substance plays a significant role in the fibrillar matrix structure of Mycetophyllia reesi (Goldberg, 2001), and (ii) the aspartic acid-rich calcium crystal surface-adsorbing structure of OPN (containing the Arg-Gly-Asp sequence) is a common feature of the soluble organic matrix in most corals (reviewed by Allemand et al., 2011). It also appears relevant that the first organic matrix protein fully characterised in corals (galaxin) is characterised by dicysteine residues that do not bind calcium (Fukuda et al., 2003). Cysteine completely inhibits the glyoxylate $\rightarrow$ oxalate conversion by acting as a glyoxalate scavenger (Dutta et al., 2007). This may provide understanding into the enigmatic role of galaxin, suggesting that it may act to control and restrict $\mathrm{CaCO}_{3}$ deposition at the skeletontissue interface; perhaps to prevent "runaway" crystal growth that would impale the overlying tissue.

\section{Model implication \#1: skeletal extension linked to dark respiration rate}

The evidence linking algal photosynthesis (most strictly ATP supply) and the rate of skeletal infilling during the 
"light-enhanced" phase of coral calcification, including potential disrupting influences (e.g., thermal stress), has been previously (favourably) reviewed (see Cohen and McConnaughey, 2003; Allemand et al., 2011) and will not be further considered here. Instead, I concentrate on the novel implication of the new biomineralisation model, namely, that for as long as carbon substrates (e.g., glucose) are available to fuel anaerobic fermentation, higher rates of dark respiration (= more severe $\mathrm{O}_{2}$-limitation) should be linked to higher rates of skeletal extension. Respiration rates integrate numerous energy-requiring processes that include both intrinsic (symbiotic) and extrinsic (environmental) drivers (Willmer et al., 2000). The respiration of reef corals has been measured for decades to gather such information (e.g., Yonge et al., 1932; Kawaguti, 1937). In this section, I explain how the new biomineralisation model is robust in its prediction with respect to both intrinsic and extrinsic drivers. Strictly speaking, the severity of $\mathrm{O}_{2}$-limitation requires consideration of demand- and supply-side dynamics. The supply of $\mathrm{O}_{2}$ across the unstirred diffusive boundary layer (DBL) that surrounds corals relates to rates of water movement and the mass transfer (size/shape) characteristics of the coral (see e.g., Nakamura and van Woesik, 2001). Initially, I choose to ignore these supply influences, but consider them in Section 5 , which outlines how environmental gradients in coral morphology (= phenotypic plasticity) are consistent with supplyside constraints.

\subsection{Intrinsic symbiotic processes}

\subsubsection{Symbiont metabolism}

The intracellular zooxanthellae contribute to the total dark respiration $\left(=\mathrm{O}_{2}\right.$ demand) of the coral symbiosis. The assumption that algal: coral respiration is proportional to algal : coral biomass $(\sim 10 \%)$ is often taken as a conservative (lower) estimate of the additional respiratory $\left(\mathrm{O}_{2}\right)$ demand contributed by the zooxanthellae (Muscatine et al., 1981). This additional respiration increases the occurrence (and severity) of $\mathrm{O}_{2}$-limitation in the dark (Rands et al., 1992; Kühl et al., 1995; Colombo-Pallotta et al., 2010), and according to the new biomineralisation model, should be matched by increased skeletal extension rates. Consistent with this expectation, Goreau (1959) found that even in the dark, corals with zooxanthellae calcified $\sim 3$ times faster than corals which had lost their zooxanthellae.

It is well established that distinct zooxanthellae phenotypes have different metabolic demands (Fitt, 1985). It is interesting to note that corals harbouring "stress" tolerant clade D1 zooxanthellae have reduced skeletal growth rates (Jones and Berkelmans, 2010); which has been interpreted as meaning that D1 is a suboptimal symbiont, despite its stress tolerance (Jones and Berkelmans, 2010). The new biomineralisation model suggests caution with this inference, since the lower skeletal growth rates may actually indicate that the coral host is undertaking less "work" to maintain the benefits of the established symbiosis. Indeed, the new model brings into question whether skeletal growth, in particular skeletal extension, is a suitable proxy for coral health in its traditional usage, i.e. enhanced extension rates should not be used as unequivocal support for a stable and efficient symbiosis. For example, controlled experiments with Pocillopora damicornis indicate that host-symbiont combinations that result in the highest skeletal extension rates under optimal $\left(26^{\circ} \mathrm{C}\right)$ temperatures are also the first to bleach and die under thermal stress $\left(30^{\circ} \mathrm{C}\right)$ (Gillette, 2012); supporting the counterintuitive (but model supported) notion that fast skeletal growth at optimal temperatures is actually a very good proxy measure for "bleaching sensitivity" under thermal stress.

\subsubsection{Cellular growth}

For both plants and animals, respiration rate is primarily regulated by cellular growth rates (Willmer et al., 2000). For symbiotic corals, the growth (division) rate of both host and zooxanthellae cells is maximal in the apical regions (e.g., tips of branching corals; Jones and Yellowlees, 1997). Consistent with model predictions, skeletal extension rates are highest in these metabolically active regions (Oliver, 1984). For the staghorn coral A. cervicornis, division rates in the apical cells of the CE display a diurnal periodicity, with maximum rates observed around midnight, and minimum rates around midday (Gladfelter, 1983b). Such an observation aligns with measurements showing that skeletal extension rates are maximal around midnight (and minimum during the day) in the closely related staghorn coral, A. grandis (Vago et al., 1997).

Furthermore, certain corals (e.g., Porites compressa) are often documented to develop raised skeletal growth anomalies, commonly referred to as "tumors" (Domart-Coulon et al., 2006). The tumors are characterised by high rates of skeletal extension (and limited thickening) which leads to a porous morphology. The host cells surrounding the tumors are highly metabolically active with elevated rates of cell proliferation (hyperplasia) (Domart-Coulon et al., 2006). It is interesting to speculate that the tumors may be the skeletal manifestation of the hyperplasia which is currently of unknown origin. Moreover, a scenario can be envisioned whereby the metabolic activities of an underpinning bacterial (or viral) load may initiate localised diseased areas with $\mathrm{O}_{2}$-depletion within the coral tissue that enforce anaerobic host fermentation; which according to the new biomineralisation model would promote a localised increase in skeletal extension. The parsimony of the model to provide an etiology of growth anomalies deserves further attention.

\subsubsection{Heterotrophic feeding}

Whilst heterotrophic metabolism typically represents a net carbon gain for corals, the process of prey capture and digestion (e.g., polyp expansion, mucus secretion, nemocyst 
release) requires respiratory input (reviewed by Houlbrèque and Ferrier-Pagès, 2009). Demersal plankton (prey) are most abundant between dusk and dawn, with densities throughout the night being at least an order of magnitude greater than daytime densities (reviewed by Fitt, 2000). Accordingly, the majority of corals only expand their tentacles to feed at night (Dubinsky and Jokiel, 1994). It is therefore again, model consistent, that skeletal extension dominates during the nighttime period (Barnes and Crossland, 1980; Vago et al., 1997).

\subsubsection{Reproduction}

The respiratory cost of generating reproductive material may also leave a detectable signal in the coral skeleton. For example, the $3 \mathrm{yr}$ profile of monthly extension rates for the branching coral A. formosa indicates that cyclical highs in skeletal extension rate occur in the 2-3 month period that precedes its two (March-April and October-November) annual spawning events (Oliver, 1985). The reproduction for massive Porites spp. on the Great Barrier Reef (Australia) has also been linked to the formation of an extension-dominated (less dense) phase of skeletal density (Gagan et al., 1996).

\subsubsection{Structural dissepiments}

An essential part of the growth process in massive perforate genera, such as Porites, is the periodic insertion of structural dissepiments (Barnes and Lough, 1989, 1993). Beyond their role in strengthening the skeletal matrix, dissepiments also serve to isolate skeleton occupied by tissue from skeleton no longer occupied by tissue (Barnes and Lough, 1993). To facilitate the dissepiment insertion process, mechanical uplift of the tissue layer is required. This uplift process occurs every $\sim 30$ days, with a suggested lunar trigger (Rotmann, 2004). During the $\sim 4-6$ day period during which the uplift process takes place, tissue (energy) reserves in massive Porites spp. reduce by $15-20 \%$, suggesting that the process is metabolically costly (Rotmann, 2004). For reasons not yet fully understood, across this same full moon period, massive Porites spp. retract their polyps and cover themselves in an extensive mucus sheet (Coffroth, 1991; True, 2005). The high respiratory cost of the uplift process (including mucus production), and the potential reduction of $\mathrm{O}_{2}$ diffusion rates due to the mucus covering, is predicted here to enhance $\mathrm{O}_{2}$-limitation (= increase skeletal extension). This prediction appears to have direct relevance with the fine density band structures that are superimposed within the more pronounced annual density couplet (Barnes and Lough, 1989). From the very first, these fine bands were equated with the lunar cycle, with the full moon period being associated with extensiondominated (low density) skeleton (Buddemeier, 1974). Since the number and spacing of fine density bands equates with the number and spacing of structural dissepiments, functional relationships have been suggested (Barnes and Lough, 1989), though a direct mechanistic link has never been elu- cidated. The new biomineralisation model provides a strong rationale by which fine density bands can be linked to the dissepiment insertion process.

\subsection{Extrinsic environmental factors}

\subsubsection{SST variability and thermal bleaching}

Previous studies have shown that coral respiration is closely related to temperature, with $\mathrm{Q}_{10}$ values $\sim 2$ to 3 within its normal temperature regime (Coles and Jokiel, 1977; Castillo and Helmuth, 2005); most likely reflecting the fundamental effects of temperature on enzyme kinetics (Hochachka and Somero, 2002). As temperatures approach the upper thermal limits of the symbiosis $\left(\sim 32^{\circ} \mathrm{C}\right)$ respiration rates are further elevated; most likely reflecting the energetic costs associated with mitigating thermal damage (Feder and Hofmann, 1999). However, prolonged exceedence of the thermal threshold can trigger symbiosis disruption (= coral bleaching) and a resultant (precipitous) reduction in respiration rate (Porter et al., 1989; Castillo and Helmuth, 2005). Consistent with the new biomineralisation model, this respiration response profile is matched by the skeletal extension rate of corals, whereby extension rates increase with temperature to a maximum and then decline (Houck et al., 1977; Mendes and Woodley, 2002), the so-called "maximum-accretion-toturnoff" response (Fig. 8a; Hallock, 2001). This response again highlights that skeletal extension is a poor indicator of symbiotic fitness, and perhaps is a best thought of as a measure of symbiosis instability; corals with fast extension rates indicative of their increased vulnerability (trajectory) toward symbiotic disruption, particularly with respect to thermal stress. Such an interpretation may contribute to understanding why corals with fast growth rates are most vulnerable to coral bleaching (Loya et al., 2001). Worryingly, this response profile appears to be evidenced by the sclerochronological signal of massive Porites coral on Australia's Great Barrier Reef (Fig. 8b; De'ath et al., 2009), with (i) a progressive increase in skeletal extension associated with known SST warming since (at least) the 1900s (Lough, 2007), followed by (ii) a precipitous decline in skeletal extension across the most recent decade, which has been punctuated by repeated mass bleaching events (Berkelmans et al., 2004). Geologically this is of major concern since recovered drill cores from "drowned" Pleistocene reef structures also typically display the "maximum-accretion-to-turnoff" response, which sees reefs accreting at their maximum rate just prior to the point at which they cease net accretion (Montaggioni, 2005).

\subsubsection{Sedimentation and eutrophication}

High-extension, low density, skeletal growth is a common sclerochronological signal of combined sedimentation and eutrophication effects on corals (Scoffin et al., 1992; Barnes and Lough, 1999; Edinger et al., 2000; 
(A) 'maximum-accretion-to-turnoff'
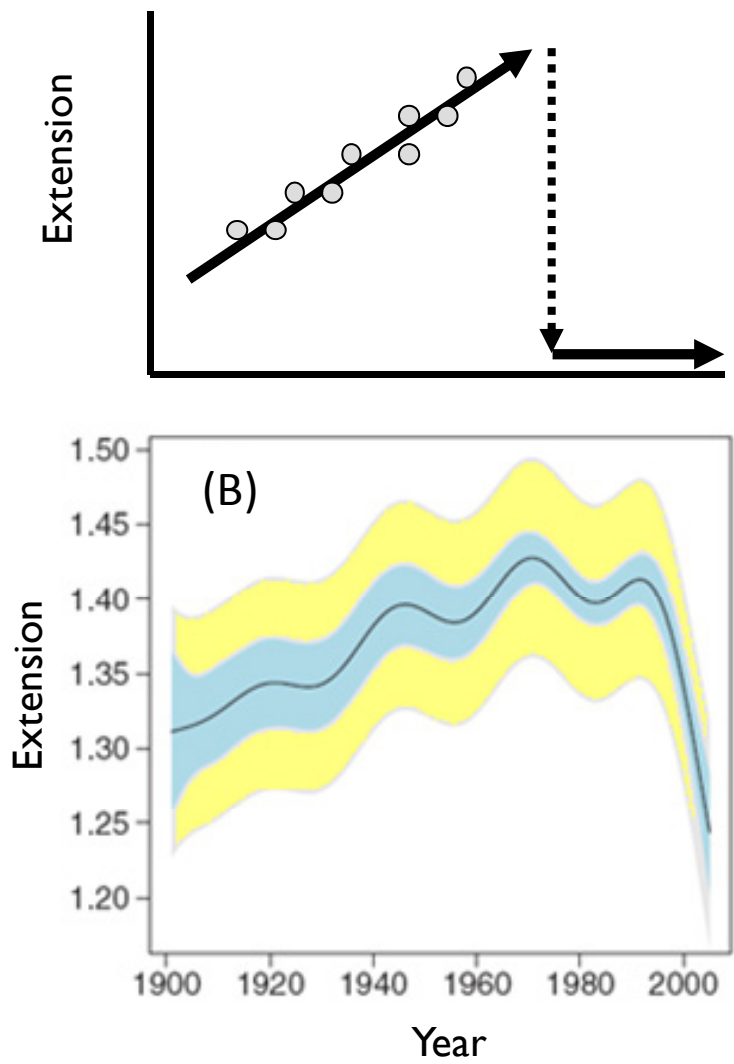

Fig. 8. (A) Schematic representation of the "maximum-accretionto-turnoff" paradox, which sees coral reefs (and individual corals) extending at their maximum rate just prior to the point at which they cease net accretion. (B) Partial-effects plot showing the variation of linear extension $\left(\mathrm{cm} \mathrm{yr}^{-1}\right)$ in massive Porites colonies on the GBR over time (1900-2005), which highlights the $13.3 \%$ decline since 1990 (adapted from De'ath et al., 2009). Blue bands indicate $95 \%$ confidence intervals for comparison between years, and yellow bands indicate $95 \%$ confidence intervals for the predicted value for any given year.

Carricart-Ganivet and Merino, 2001). The enhanced respiration rate of symbiotic corals in response to elevated levels of inorganic nutrients and sediments (Ferrier-Pagès et al., 2000; Anthony and Fabricius, 2000) means that such a response is consistent with the new biomineralisation model. For nutrients, the increased respiration appears to be mediated via a significant enlargement (by as much as a factor of 2-3) of the zooxanthellae population (Ferrier-Pagès et al., 2000). For sediments, the cleaning and sediment rejections processes (e.g., ciliary-mucus mechanism; Stafford-Smith, 1993) are metabolically very costly (Anthony and Fabricius, 2000).

\subsubsection{Ocean acidification}

Ocean acidification $(\mathrm{OA})$ that reduces the $\mathrm{pH}$ and thus the abundance of $\mathrm{CO}_{3}^{-2}$ ions in seawater is known to disrupt the skeletogenesis process of marine calcifying organisms, including corals with a variety of mechanisms identified as potential triggering agents (reviewed by Kleypas and Langdon, 2006). The new biomineralisation model may contribute additional insight into these mechanisms, most specifically in the area of coral energetics and the proposed link to skeletal extension rates. Since the concentration of $\mathrm{CO}_{3}^{-2}$ ions relative to other carbonate species in seawater is low, calcification under any circumstance is energetically costly (e.g., $\mathrm{Ca}^{2+}$-ATPase pump activation), but is predicted to be even more costly as the acidity of the ocean increases (Cohen and Holcomb, 2009). Moreover, provided nutrients are not limiting, the zooxanthellae may respond to $\mathrm{pH}$ reductions (i.e. increase $p \mathrm{CO}_{2}$ ) by increasing their background density within the host, particularly in the cooler months (RodolfoMetalpa et al., 2010; Wooldridge, 2012). The new biomineralisation model predicts that the increased respiratory cost of these outcomes will act to enhance skeletal extension rates (but not necessarily skeletal density or overall calcification rates) for as long as sufficient host energy reserves exist. On this note, it appears relevant that reductions in $\mathrm{CO}_{3}^{-2}$ have been observed to initiate "elongated and much narrower" crystal fibre growth in certain coral species (c.f. Marubini et al., 2003). It is also conceivable that this response has contributed to the increased rate of skeletal extension on the GBR since the 1900s (Fig. 8b); where pH is predicted to have dropped by about $0.2-0.3$ units from the 1940 s to the present day (Wei et al., 2009).

Whilst corals may compensate for elevated energy demand during moderate (or short-term high) OA stress by elevating metabolic flux to cover ATP demand, as $\mathrm{pH}$ stress levels increase to disrupt fundamental acid-base cellular processes, it is predicted that corals (and other marine organisms) will enter a metabolically depressed state to conserve energy and to extend the survival time until the conditions return to the optimum (Guppy and Withers, 1999). Such a response may be commensurate with the observations of Kaniewska et al. (2012), who measured a 3-fold reduction in dark respiration in the reef coral A. millepora when exposed to seawater at $\sim \mathrm{pH}$ 7.6. (see also Edmunds, 2012). In this case, the new biomineralisation model predicts a significant reduction in skeletal extension. Notably, high precision (optical micrometer) measurements of skeletal extension rates in P. lobata indicate an immediate but reversible $45-80 \%$ reduction in skeletal extension at $\mathrm{pH} \sim 7.6$ (Langdon, unpublished data). Future experiments are needed to identify the $\mathrm{pH}$ threshold where the predicted metabolic depression is initiated; which may be species specific, and will almost certainly be co-determined by any associated level of thermal stress (Pörtner, 2010); especially if it initiates a thermal coral bleaching response (Anthony et al., 2008). 


\section{Model implication \#2: vital effect on oxygen and carbon stable isotope composition}

The aragonite deposited by corals is typically depleted in ${ }^{13} \mathrm{C}$ and ${ }^{18} \mathrm{O}$ relative to values of isotopic equilibrium with ambient seawater (Weber and Woodhead, 1970; McConnaughey, 1989). Moreover, the extent of disequilibrium (the so-called "vital effect") displays strong spatial coherence with structural growth characteristics of the coral, for example, (i) the granular crystals of the COC are more depleted in both ${ }^{13} \mathrm{C}$ and ${ }^{18} \mathrm{O}$ compared with the surrounding aragonite fibres (Rollion-Bard et al., 2003a, 2003b; Meibom et al., 2006), (ii) structural dissepiments are associated with $\mathrm{CaCO}_{3}$ that is more strongly depleted in ${ }^{18} \mathrm{O}$ (RollionBard et al., 2003a), and (iii) rapidly extending areas within a colony are depleted in both ${ }^{13} \mathrm{C}$ and ${ }^{18} \mathrm{O}$ compared with slower extending areas (Land et al., 1975; McConnaughey, 1989; Suzuki et al., 2005). In a variety of different ways, these structural relations challenge the robustness of the current geochemical explanation(s) of vital effects in corals (reviewed by Rollion-Bard et al., 2010), especially given new evidence from boron isotope data showing that the carbonate within the $\mathrm{COC}$ is deposited at lower $\mathrm{pH}$ compared with the surrounding fibres (Rollion-Bard et al., 2003a). These inconsistencies caused Rollion-Bard et al. (2010) to question the existence of a continuous (common) fluid layer domain for cystralization of COCs and fibres.

However, the geochemical consequences of the new coral biomineralisation model can reconcile carbon and oxygen isotope vital effects whilst maintaining the common fluid layer concept. Fundamental to this explanation is a reconsideration of the role (and dynamics) of respiratory carbon dioxide $\left(\mathrm{CO}_{2 \mathrm{met}}\right)$ used in calcification - as compared to seawater dissolved inorganic carbonate (DIC) (cf. Weber and Woodhead, 1970). In this case, it is important to note that zooxanthellae photosynthesis preferentially uses the lighter ${ }^{12} \mathrm{C}$, and thus transfer of zooxanthellae photoassimilates (i.e. autotrophic carbon) to the coral host enriches the tissue biomass in ${ }^{12} \mathrm{C}$ relative to ${ }^{13} \mathrm{C}$ (Muscatine et al., 1989). Heterotrophic carbon sources (e.g. zooplankton) are even more depleted in ${ }^{13} \mathrm{C}$ (Muscatine et al., 1989). Metabolic respiration thus preferentially adds ${ }^{12} \mathrm{CO}_{2 \text { (met) }}$ into the common carbon pool, and since ${ }^{16} \mathrm{O}$ is preferentially consumed during respiration (Lane and Dole, 1956), the respired $\mathrm{CO}_{2(\mathrm{met})}$ is also depleted in ${ }^{18} \mathrm{O}$. In this way, if respiratory $\mathrm{CO}_{2 \text { (met) }}$ were to be increasingly used as a source of carbon and oxygen for skeleton formation, both elements in the carbonate would be enriched in the lighter isotopes with respect to $\mathrm{CaCO}_{3}$ which might form from seawater "inorganically".

Isotope labelling experiments confirm that respiratory $\mathrm{CO}_{2 \text { (met) }}$ is incorporated into coral skeletons, though uncertainty exists as to its relative importance to seawater DIC (Pearse, 1971; Furla et al., 2004). For the new biomineralisation model, the amount of respiratory $\mathrm{CO}_{2 \text { (met) }}$ available for calcification is predicted to vary significantly with the "light" and "dark" phases of calcification. During the "light" phase, enhanced (ATP-dependent) activity of $\mathrm{Ca}^{2+}$ ATPase provides efficient (stepwise) access to bulk seawater DIC. For the "dark" phase, $\mathrm{O}_{2}$-limitation that restricts (ATPdependent) activity of $\mathrm{Ca}^{2+}$-ATPase acts to reduce easy access to bulk seawater DIC - and in conjunction with limited $\mathrm{CO}_{2 \text { (met) }}$ uptake for zooxanthellae photosynthesis, it provides the opportunity for respiratory $\mathrm{CO}_{2 \text { (met) }}$ to becoming increasing available at the site of calcification (relative) to seawater DIC. Thus, consistent with the above outlined vital effects, the new biomineralisation model predicts that (i) the granular crystals of the COC (and the associated rapid extending dimension of skeletal growth) linked with "dark" calcification will be enriched in respiratory $\mathrm{CO}_{2 \text { (met) }}$ and thus depleted in both ${ }^{13} \mathrm{C}$ and ${ }^{18} \mathrm{O}$, whilst (ii) aragonite fibre growth and consolidation linked with "light" calcification will be comparatively depleted in respiratory $\mathrm{CO}_{2 \text { (met) }}$ and thus less depleted in both ${ }^{13} \mathrm{C}$ and ${ }^{18} \mathrm{O}$. Moreover, the continual $(\sim$ several months; Barnes and Lough, 1993) thickening/consolidation of skeletal elements, predicted here to occur primarily during the "light" phase of calcification, means that the carbon and oxygen isotope composition will become progressively diluted towards the $\mathrm{Ca}^{2+}$-ATPase reliant ("heavier") seawater signal the longer the $\mathrm{CE}$ remains in contact with the accreting skeletal surface; which is consistent with new timelapsed measurements (Mizrachi et al., 2010).

The proposed importance of $\mathrm{Ca}^{2+}$-ATPase activity in controlling the comparative amount of respiratory $\mathrm{CO}_{2 \text { (met) }}$ used in calcification also retains relevance for periods of bleaching (= zooxanthellae expulsion) wherein reduced ATP availability (Fang et al., 1991) can be reasonably expected to limit $\mathrm{Ca}^{2+}$-ATPase activity. In this case, the new biomineralisation model predicts that the skeleton will become comparatively enriched in respiratory $\mathrm{CO}_{2 \text { (met) }}$; being consistent with observations showing that coral skeletons are more heavily depleted in both ${ }^{13} \mathrm{C}$ and ${ }^{18} \mathrm{O}$ during bleaching periods (see e.g., Leder et al., 1991).

\section{Model implication \#3: the phenotypic response of corals to water movement}

Scleractinian corals display a striking degree of morphological variation in colony shape and corallite structure along environmental gradients, particularly water movement (see e.g., Dustan, 1975; Sebens and Done, 1992; Bruno and Edmunds, 1997). Growth forms typically show a gradual transition from a compact shape, under exposed (high-energy forereef) conditions, to a thinner branching shape under sheltered (low-energy back reef or lagoonal) conditions (Fig. 9; Veron and Pichon, 1976). Such morphological variation are reflected in the annual extension and density pattern of massive growth forms (e.g. Porites, Montastraea and Diploria), where linear extension rates are lowest and bulk densities highest at the most exposed reef sites (Hudson, 1981; 
Isdale, 1983; Scoffin et al., 1992; Logan et al., 1994). Whilst these growth patterns have been speculated to be beneficial in terms of resisting wave damage, a coherent mechanism underpinning the response has been lacking, even causing some to test if it may be a result of genetic factors (Bruno and Edmunds, 1997). However, the new coral biomineralisation model provides a parsimonious explanation in terms of enhanced $\mathrm{O}_{2}$ delivery (diffusion) at exposed (high-energy) sites, leading to less severe dark $\mathrm{O}_{2}$-limitation $(=$ reduced skeletal extension). It is well established that aerobic respiration in adult corals is flow-dependent in the dark (Patterson et al., 1991), supportive of the suggestion that symbiotic corals becomes less $\mathrm{O}_{2}$-limited as flow rates increase; thereby placing a lower requirement on the process of anaerobic fermentation. Interestingly, smaller corals (and recruits) that have higher mass transfer (diffusion) rates than larger corals (Nakamura and van Woesik, 2001) are not significantly $\mathrm{O}_{2}$-limited at low $\left(<27^{\circ} \mathrm{C}\right) \mathrm{SST}$, but become $\mathrm{O}_{2}$ limited at higher $\left(>29^{\circ} \mathrm{C}\right) \mathrm{SST}$ due to heavier $\left(\mathrm{Q}_{10}\right)$ oxygen demands, with the result that respiration only becomes flow dependent at high SST (Edmunds, 2005). Such a response is model consistent with ontological effects seen in massive Porites cores whereby annual extension rates progressively increase with size (age) (Lough, 2011).

\section{Model implication \#3: a contributing explanation for the Cambrian explosion of metazoa?}

The Proterozoic-Cambrian transition is marked in the sedimentary record by the sudden appearance of mineralized skeletons (in particular of $\mathrm{CaCO}_{3}$ ), indicating that calcification mechanisms were acquired nearly simultaneously by most invertebrate taxa between 545 and 535 million yr ago; coincident with the so-called "Cambrian explosion" of most known animal phyla (reviewed by Marshall, 2006). The fact that highly organised skeletons appeared nearly simultaneously in many different taxa requires an intrinsic mechanism. Some authors have speculated that the introduction of calcifying machinery represents a major reorganization of calcium metabolism within the cell (Lowenstam and Margulis, 1980). The proposed homeostatic role of calcification to offset respiratory $\mathrm{O}_{2}$-limitation in cnidarians provides an additional intrinsic evolutionary "invention"; being commensurate with the understanding that: (i) $\mathrm{O}_{2}$-limitation was a fundamental constraint limiting Precambrian taxa (Marshall, 2006), and (ii) strong (but unexpected) cross-reactivities exist between the soluble skeletal organic matrix of unrelated taxa, such as brachiopods, molluscs, and corals (Marin et al., 1996).

A fundamental qualifying constraint for this new suggestion relates to timing, and requires that the origin of cnidarians aligns with the known evolutionary linage of metozoa. Indeed, the oldest fossils that can be confidently called cnidarians are 540 million yr old, and DNA mutation esti-

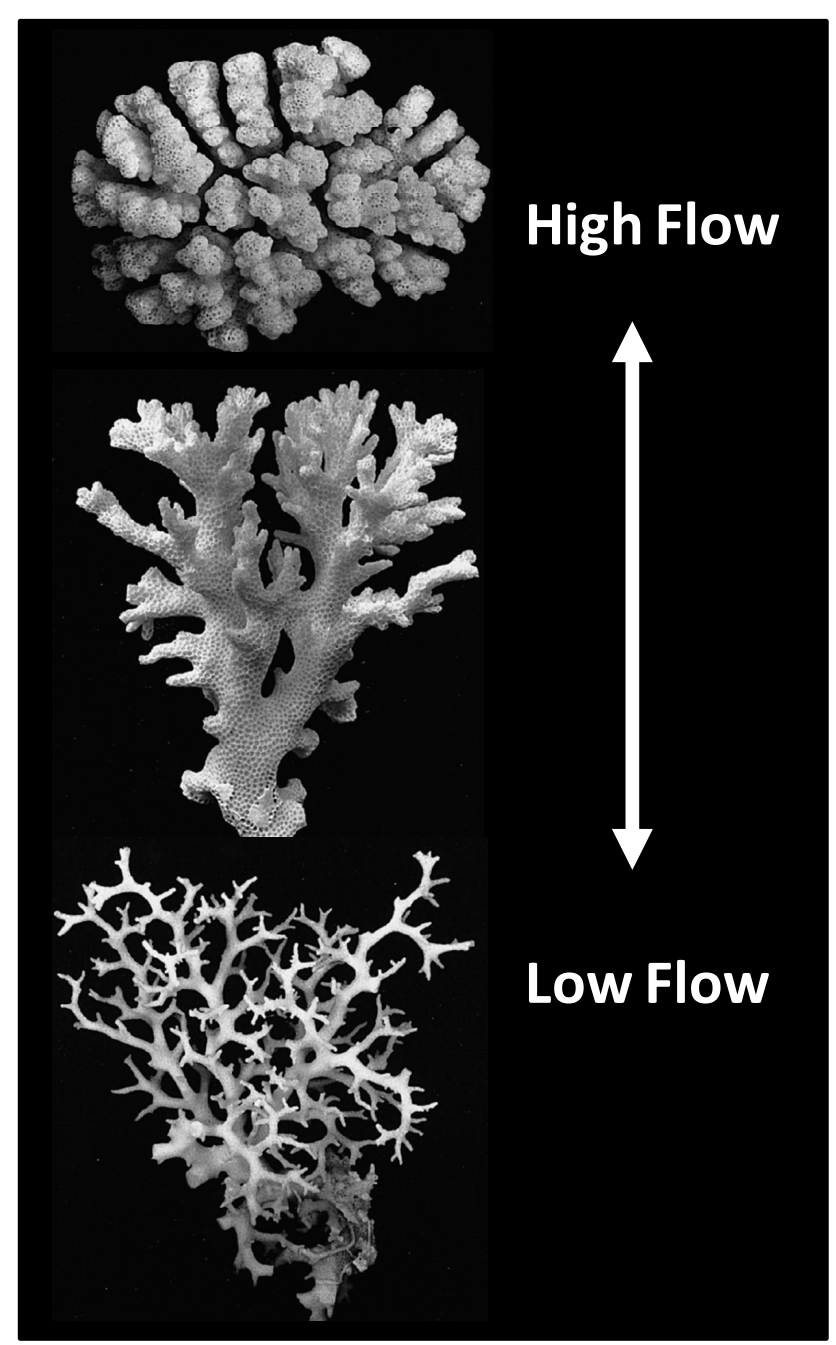

Fig. 9. A range of growth forms from a single species of $P$. damicornis (after Veron and Pichon, 1976).

mates suggest that the common ancestor of living cnidarians lived 543 million yr ago (Peterson et al., 2005). This suggests that cnidarians may not have been the simple forerunners of the Cambrian explosion, but very much part of it; a view that is supported by new research showing that that a number of genes once thought to be unique to vertebrates have turned up in the genomes of cnidarians, indicating that these genes did not, in fact, arise in early vertebrates (Pennisi, 2007). The relevance being, that cnidarians could ultimately prove a better model for human biology than fruit flies (Pennisi, 2007).

Obviously, the strength of the evidence provided within the current manuscript precludes strong inference being made about this new Cambrian explosion hypothesis. It does however serve to highlight the wide ranging implications of the proposed biomineralisation model, and why future testing and refinement is important. 


\section{Concluding comment}

This paper has proposed a new paradigm to explain coral biomineralisation, wherein the morphological attribute of skeletal extension has been linked to the physiological requirements of the coral host to ensure its metabolic status during periods of $\mathrm{O}_{2}$-limitation. The new paradigm has been shown to be consistent across multiple scales of observation, and perhaps better reconciles the long-standing question of why corals expend so much energy in depositing extensive skeletons, only to live in the last few millimetres of it.

The conceptual nature of the model means that many of the proposed linkages remain to be described and tested in their entirety; most notably relating to the dynamic functioning of the CE leading to the delivery of organic material at the skeletal-tissue interface, and the formation of small pockets of uplifted tissue into which the incipient skeletal framework extends. Other more basic uncertainties common to all previous models (e.g., a complete characterisation of the suite of delivery mechanisms for $\mathrm{Ca}^{2+}$ and $\mathrm{CO}_{3}^{2-}$ ions from bulk seawater to the site of calcification) also remain to be resolved.

Notwithstanding these areas of uncertainty, the interpretive capacity provided by the new model is noteworthy, since it provides a fresh standpoint for utilising skeletal ultrastructure chronologies as instructors of past, present and future challenges to the viability of the coral-algae endosymbiosis. This new standpoint warns that the precipitous (globalwide) declines in the extension rate of coral skeletons (see e.g., De'ath et al., 2009; Tanzil et al., 2009; Bak et al., 2009) is symptomatic of an emerging envelope of environmental conditions - characterised by elevated SST, rising $p \mathrm{CO}_{2}$ and enriched inorganic nutrient levels - that is unfavourable to the near-future persistence of the coral-algae endosymbiosis (sensu Wooldridge 2009a, 2009b, 2010, 2012). Future testing and refinement of the ideas presented within this paper offers considerable hope for developing further insights into tackling the climate-induced demise of coral-algae symbioses and the reefs they construct.

Acknowledgements. This manuscript benefited from the interactive comments (and criticism) of two anonymous reviewers. An archived record of this peer review, including author responses, is available at: http://www.biogeosciences-discuss.net/9/12627/2012/ bgd-9-12627-2012-discussion.html

Edited by: A. Shemesh

\section{References}

Al-Horani, F. A., Al-Moghrabi, S. M., and De Beer, D.: The mechanism of calcification and its relation to photosynthesis and respiration in the scleractinian coral, Galaxea fascicularis, Mar. Biol., 142, 419-426, 2003.

Allemand, D., Tambutté, E., Girard, J. P., and Jaubert, J.: Organic matrix synthesis in the scleractinian coral Stylophora pistillata: role in biomineralization and potential target of the organotin tributyltin, J. Exp. Biol., 201, 2001-2009, 1998.

Allemand, D., Tambutté, E., Zoccola, D., and Tambutté, S.: Coral calcification, cells to reefs, in: Coral reefs: an ecosystem in transition, edited by: Dubinsky, Z. and Stambler, N., Springer, 119150, 2011.

Anthony, K. R. N. and Fabricius, K. E.: Shifting roles of heterotrophy and autotrophy in coral energetics under varying turbidity, J. Exp. Mar. Biol. Ecol., 252, 221-253, 2000.

Anthony, K. R. N, Kline, D. I., Diaz-Pulido, G., Dove, S., and Hoegh-Guldberg, O.: Ocean acidification causes bleaching and productivity loss in coral reef builders, P. Nat. Acad. Sci. USA, 105, 17442-17446, 2008.

Asselman, M., Verhulst, A., De Broe, M. E., and Verkoelem, C. F.: Calcium oxalate crystal adherence to Hyaluronan-, Osteopontin, and CD44-expressing injured/regenerating tubular epithelial cells in rat kidneys, J. Am. Soc. Nephrol., 14, 3155-3166, 2003.

Bak, R. P. M., Nieuwland, G., and Meesters, E. H.: Coral growth rates revisited after 31 years: what is causing lower extension rates in Acropora palmata?, Bull. Mar. Sci., 84, 287-294., 2009.

Barnes, D. J.: Coral skeletons: An explanation of their growth and structure, Science, 170, 1305-1308, 1970.

Barnes, D. J. and Crossland, C. J.: Diurnal and seasonal variations in the growth of a staghorn coral measured by time-lapse photography, Limnol. Oceanogr., 25, 1113-1117, 1980.

Barnes, D. J. and Devereux, M. J.: Productivity and calcification on a coral reef: a survey using $\mathrm{pH}$ and oxygen electrode techniques, J. Exp. Mar. Biol. Ecol., 79, 213-231, 1984.

Barnes, D. J. and Lough, J. M.: The nature of skeletal density banding in scleractinian corals: fine banding and seasonal patterns, J. Exp. Mar. Biol. Ecol., 126, 119-134, 1989.

Barnes, D. J. and Lough, J. M.: On the nature and causes of density banding in massive coral skeletons, J. Exp. Mar. Biol. Ecol., 167, 91-108, 1993.

Barnes, D. J. and Lough, J. M.: Porites growth characteristics in a changed environment: Misima Island, Papua New Guinea, Coral Reefs, 18, 213-218, 1999.

Barrington, E. J. W.: Invertebrate structure and function, John Wiley and Sons, New York, 765 pp., 1979.

Berkelmans, R., De'ath, G., Kininmonth, S., and Skirving, W. J.: A comparison of the 1998 and 2002 coral bleaching events on the Great Barrier Reef: spatial correlation, patterns and predictions, Coral Reefs, 23, 74-83, 2004.

Blamart, D., Rollion-Bard, C., Meibom, A., Cuif, J.-P., JuilletLeclerc, A., and Dauphin, Y.: Correlation of boron isotopic composition with ultrastucture in deep-sea coral Lophelia pertusa: Implications for biomineralization and paleo-pH, Geochem. Geophy. Geosy., 8, Q12001, doi:10.1029/2007GC001686, 2007.

Bruno, J. F. and Edmunds, P. J.: Clonal variation for phenotypic plasticity in the coral Madracis Mirabillis, Ecology, 78, 21772190, 1997.

Bryan, W. B. and Hill, D.: Spherulitic crystallization as a mechanism of skeletal growth in the hexacorals, Proc. R. Soc. Queensland, 52, 78-91, 1941.

Buddemeier, R. W.: Environmental controls over annual and lunar monthly cycles in hermatypic coral calcification, Proc. 2end Int. Coral Reef Symp., 2, 259-267, 1974.

Busa, W. B.: Mechanisms and consequences of $\mathrm{pH}$-mediated cell regulation, Annu. Rev. Physiol., 48, 389-402, 1986. 
Carricart-Ganivet, J. P. and Merino, M.: Growth responses of the reef-building coral Montastraea annularis along a gradient of continental influence in the southern Gulf of Mexico, Bull. Mar. Sci., 68, 133-146, 2001.

Castillo, K. D. and Helmuth, B. S. T.: Influence of thermal history on the response of Montastraea annularis to short-term temperature exposure, Mar. Biol., 148, 261-270, 2005.

Chalker, B. E.: Calcium transport during skeletogenesis in hermatypic corals, Comp. Biochem. Physiol., 54, 455-459, 1976.

Chalker, B. E. and Taylor, D. L.: Light-enhanced calcification, and the role of oxidative phosphorylation in calcification of the coral Acropora cervicornis, Proc. R. Soc. Lond. B., 190, 323-331, 1975.

Clode, P. L. and Marshall, A. T.: Low temperature FESEM of the calcifying interface of a scleractinian coral, Tissue Cell, 34, 187198, 2002.

Coffroth, M. A.: Cyclical mucous sheet formation on poritid corals in the San Blas Islands, Panama, Mar. Biol., 109, 35-40, 1991.

Cohen, A. L. and Holcomb, M.: Why corals care about ocean acidification: uncovering the mechanism, Oceanograhpy, 22, 118127, 2009.

Cohen, A. L. and McConnaughey, T. A.: Geochemical perspectives on coral mineralization, Rev. Mineral. Geochem., 54, 151-187, 2003.

Coles, S. L. and Jokiel, P. L.: Effects of temperature on photosynthesis and respiration in hermatypic corals, Mar. Biol., 43, 209-216, 1977.

Colombo-Pallotta, M. F., Rodriguez-Roman, A., and IglesiasPrieto, R.: Calcification in bleached and unbleached Montastraea faveolata: evaluating the role of oxygen and glycerol, Coral Reefs, 29, 899-907, 2010.

Constantz, B. and Weiner, S.: Acidic macromolecules associated with the mineral phase of scleractinian coral skeletons, J. Exp. Zool., 248, 253-258, 1988.

Crossland, C. J. and Barnes, D. J.: The role of metabolic nitrogen in coral calcification, Mar. Biol., 28, 325-332, 1974.

Cuif, J. P. and Dauphin, Y.: The environmental recording unit in coral skeletons: structural and chemical evidences of a biochemically driven stepping-growth process in coral fibres, Biogeosciences, 2, 61-73, 2005, http://www.biogeosciences.net/2/61/2005/.

De' ath, G., Lough, J. M., and Fabricius, K. E.: Declining coral calcification on the Great Barrier Reef, Science, 323, 116-119, 2009.

Denny, M. W.: Biology and the mechanics of the wave-swept environment, Princeton Univ. Press, Princeton, NJ, 329 pp., 1988.

Domart-Coulon, I. J., Traylor-Knowles, N., Peters, E., Elbert, D., Downs, C., Price, K., Stubbs, J., McLaughlin, S., Cox, E., Aeby, G., Randy-Brown, P., and Ostrander, G. K.: Comprehensive characterization of skeletal tissue growth anomalies of the finger coral Porites compressa, Coral Reefs, 25, 531-543, 2006.

Dubinsky, Z. and Jokiel, P. L.: Ratio of energy and nutrient fluxes regulates symbiosis between zooxanthellae and corals, Pac. Sci., 48, 313-324, 1994.

Dustan, P.: Growth and form in the reef building coral Montastrea annularis, Mar. Biol., 33, 101-107, 1975.

Dutta, U., Cohenford, M. A., Guha, M., and Dain, J. A.: Nonenzymatic interactions of glyoxylate with lysine, arginine, and glucosamine: a study of advanced non-enzymatic glycation like compounds, Bioorg. Chem., 35, 11-24, 2007.
Edinger, E. N., Limmon, G. V., Jompa, J., Widjatmoko, W., Heikoop, J., and Risk, M.: Normal coral growth rates on dying reefs: are coral growth rates good indicators of reef health?, Mar. Pollut. Bull., 40, 404-425, 2000.

Edmunds, P. J.: Effect of elevated temperature on aerobic respiration of coral recruits, Mar. Biol., 146, 655-633, 2012.

Edmunds, P. J.: Effect of $p \mathrm{CO}_{2}$ on the growth, respiration, and photophysiology of massive Porites spp. in Moorea, French Polynesia, Mar. Biol., 159, 2149-2160, 2012.

Ellington, W. R.: Aerobic and anaerobic degradation of glucose by the estuarine sea anemone, Diadumene leucolena, Comp. Biochem. Physiol., 58B, 173-175, 1977.

Ellington, W. R.: Some aspects of the metabolism of the sea anemone Haliplanella luciae (Verrill) during air exposure and hypoxia, Mar. Biol. Lett., 1, 255-262, 1980.

Fang, L. S., Chen, Y. W., and Chen C. S.: Feasibility of using ATP as an index for environmental stress on hermatypic coral, Mar. Ecol.-Prog. Ser., 70, 257-262, 1991.

Feder, M. E. and Hofmann, G. E.: Heat-shock proteins, molecular chaperones, and the stress response, Annu. Rev. Physiol., 61, 243-282, 1999.

Ferrier-Pagès, C., Gattuso, J. P., Dallot, S., and Jaubert, J.: Effect of nutrient enrichment on growth and photosynthesis of the zooxanthellate coral Stylophora pistillata, Coral Reefs, 19, 103-113, 2000.

Fitt, W. K.: Effect of different strains of zooxanthella Symbiodinium microadriaticum on growth and survival of their coelenterate and molluscan hosts, Proc 5th Int. Coral Reef Symp., 6, 131-136, 1985.

Fitt, W. K.: Cellular growth of host and symbiont in a cnidarianzooxanthellar symbiosis, Biol. Bull., 198, 110-120, 2000.

Fukuda, I., Ooki, S., Fujita, T., Murayama, E., Nagasawa, H., Isa, Y., and Watanabe, T.: Molecular cloning of a cDNA encoding a soluble protein in the coral exoskeleton, Biochem. Bioph. Res. Co., 304, 11-17, 2003.

Furla, P., Galgani, I., Durand, I., and Allemand D.: Sources and mechanisms of inorganic carbon transport for coral calcification and photosynthesis. J. Exp. Biol., 203, 3445-3457, 2004.

Gabriel, D. A. and Carr, M. E.: Calcium destabilizes and causes conformational changes in hyaluronic acid, Am. J. Med. Sci., 1, 8-14, 1989.

Gagan, M. K., Chivas, A. R., and Isdale, P. J.: Timing coral-based climatic histories using ${ }^{13} \mathrm{C}$ enrichments driven by synchronised spawning, Geology, 24, 1009-1012, 1996.

Gateńo, D., Israel A., Barki Y., and Rinkevich, B.: Gastrovascular circulation in an octocoral: evidence of significant transport of coral and symbiont cells, Biol. Bull., 194, 178-186, 1998.

Gillette, P.: Intraspecific genetic variability in temperature tolerance in the coral Pocillopora damicornis: Effects on growth, photosynthesis and survival, PhD Thesis, University of Miami, USA, 2012.

Gladfelter, E. H.: Skeletal development in Acropora cervicornis. 1. Patterns of calcium carbonate accretion in the axial corallite, Coral Reefs, 1, 45-51, 1982.

Gladfelter, E. H.: Skeletal development in Acropora cervicornis. Diel patterns of calcium carbonate accretion, Coral Reefs, 2, 91100, 1983a.

Gladfelter, E. H.: Spatial and temporal patterns of mitosis in the cells of the axial polyp of the reef coral Acropora cervicornis, 
Biol Bull., 165, 811-815, 1983 b.

Goldberg, W. M.: Acid polysaccharides in the skeletal matrix and calicoblastic epithelium of the stony coral Mycetophyllia reesi, Tissue Cell, 33, 376-387, 2001.

Goreau, T. F.: The physiology of skeleton formation in corals. 1. A method for measuring the rate of calcium deposition by corals under different conditions, Biol. Bull., 116, 59-75, 1959.

Gourlay, I. D. and Grime, G. W.: Calcium oxalate crystals in African Acacia species and their analysis by scanning proton microprobe (SPM), Iawa J., 15, 137-148, 1994.

Grieshaber, M. K., Hardewig, I., Kreutzer, U., and Pörtner, H-O.: Physiological and metabolic responses to hypoxia in invertebrates, Rev. Physiol. Bioch. P., 125, 43-147, 1994.

Guppy, M. and Withers, P.: Metabolic depression in animals: physiological perspectives and biochemical generalizations, Biol. Rev., 74, 1-40, 1999.

Hadler, N. M., Dourmashkin, R. R., Nermut, M. V., and Williams, L. D.: Ultrastructure of a hyaluronic acid matix, P. Natl. Acad. Sci. USA, 79, 307-309, 1982.

Hallock, P.: Coral reefs, carbonate sediments, nutrients, and global change, in: The history and sedimentology of ancient reef systems, edited by: Stanley, G., Kluwer Academic/Plenum Publishers, NY, 387-427, 2001.

Hochachka, P. W. and Somero, G. N.: Biochemical adaptations, Oxford University Press, Oxford, 2002.

Hochachka, P. W., Fields, J., and Mustafa, T.: Animal life without oxygen: Basic biochemical mechanisms, Am. Zool., 13, 543$555,1973$.

Houck, J. E., Buddemeier, R. W., Smith S. V., and Jokiel, P. L.: The response of coral growth and skeletal strontium content to light intensity and water temperature, Proc 3rd Int. Coral Reef Symp., 2, 424-431, 1977.

Houlbrèque, F. and Ferrier-Pagès, C.: Heterotrophy in tropical scleractinian corals, Biol. Rev. Camb. Philos., 84, 1-17, 2009.

Hudson, J. H.: Growth rates in Montastrea annularis: a record of environmental change in Key Largo Reef Marine Sanctuary, Florida, Bull. Mar. Sci., 31, 444-459, 1981.

Isa, Y.: An electron microscope study on the mineralization of the skeleton of the staghorn coral Acropora hebes, Mar. Biol., 93, 91-101, 1986.

Isdale, P. J.: Geographical patterns in coral growth on the Great Barrier Reef, in: Proc. of the Great Barrier Reef conference, edited by: Baker, J. T., Carter, R. M., Sammarco, P. W., and Stark, K. P., James Cook Univ. Press, Townsville, 327-330, 1983.

Johnston, I. S.: The ultrastructure of skeletogenesis in hermatypic corals, Int. Rev. Cytol., 67, 171-214, 1980.

Jones, A. and Berkelmans, R.: Potential costs of acclimatization to a warmer climate: growth of a reef coral with heat tolerant vs. sensitive symbiont types, PLoS ONE, 5, e10437, doi:10.1371/journal.pone.0010437, 2010.

Jones, R. J. and Yellowlees, D. I.: Regulation and control of intracellular algae (= zooxanthellae) in hard corals, Phil. Trans. Roy. Soc. B, 352, 457-468, 1997.

Kaniewska, P., Campbell, P. R., Kline, D. I., RodriquezLanetty, M., Miller, D. J., Dove, S., and Hoegh-Guldberg, O.: Major cellular and physiological impacts of ocean acidification on a reef building coral, PloS ONE, 7, e34659, doi:10.1371/journal.pone.0010437, 2012.
Kawaguti, S.: On the physiology of reef corals 1 . On the oxygen exchanges of reef corals, Palao. Trop. Biol. Stn. Stud., 1, 187198, 1937.

Kleypas, J. A. and Langdon, C.: Coral reefs and changing seawater chemistry, in: Coral Reefs and Climate Change: Science and Management, AGU Monograph Series, Coastal and Estuarine Studies, American Geophysical Union, Washington DC, 61, 73110, 2006.

Kondrashov, F., Koonin, E. V., Morgunov, I. G., Finogenova, T., and Kondrashova, M. N.: Evolution of the glyoxylate cycle enzymes in Metazoa: evidence of multiple horizontal transfer events and pseudogene formation, Biol. Direct, 1, 1-31, 2006.

Kühl, M., Cohen, Y., Dalsgaard, T., Jorgensen, B. B., and Revsbech, N. P.: Microenvironment and photosynthesis of zooxanthellae in scleractinian corals studied with microsensors for $\mathrm{O}_{2}, \mathrm{pH}$ and light, Mar. Ecol.-Progr. Ser., 117, 159-172, 1995.

Lamontagne, C.-A., Plante, G. E., and Grandbois, M.: Characterization of hyaluronic acid interaction with calcium oxalate crystals: implication of crystal faces, $\mathrm{pH}$ and citrate, J. Mol. Recognit., 24, 733-740, 2011.

Land, L. S., Lang J. C., and Barnes D. J.: Extension rate: A primary control on the isotopic composition of West Indian (Jamaican) scleractinian reef coral skeletons, Mar. Biol., 33, 221-233, 1975.

Lane, G. A. and Dole, M.: Fractionation of oxygen isotopes during respiration, Science, 123, 574-576, 1956.

Leder, J. J., Szmant, A. M., and Swart, P. K.: The effect of prolonged "bleaching" on skeletal banding and stable isotopic composition in Montastrea annularis, Coral Reefs, 10, 19-27, 1991.

Le Tissier, M.: Diurnal patterns of skeletal formation in Pocillopora damicornis (Linneaus), Coral Reefs, 7, 81-88, 1988.

Le Tissier, M.: The nature of the skeleton and skeletogenic tissues in the Cnidaria, Hydrobiologia, 216-217, 397-402, 1991.

Logan, A. and Tomascik, T.: Linear extension growth rates in two species of Diploria from high-latitude reefs of Bermuda, Coral Reefs, 13, 225-230, 1994.

Lough, J. M.: Measured coral luminescence as a freshwater proxy: comparison with visual indices and a potential age artefact, Coral Reefs, 30, 169-182, 2011.

Lough, J. M.: Climate and climate change on the Great Barrier Reef, in: Climate change and the Great Barrier Reef: A vulnerability assessment, Great Barrier Reef Marine Park Authority and the Australian Greenhouse Office, edited by: Johnson, J. E. and Marshall, P. A., Department of the Environment and Water Resources, 15-50, 2007.

Lowenstam, H. A. and Margulis, L.: Evolutionary prerequisites for early phanerozoic calcareous skeletons, BioSystems, 12, 27-41, 1980.

Loya, Y., Sakai, K., Yamazato, K., Nakano, Y., Sambali, H., and van Woesik, R.: Coral bleaching: the winners and the losers, Ecol. Lett., 4, 122-131, 2001.

Lu, Y., Wu, Y.-R., and Han, B.: Anaerobic induction of isocitrate lyase and malate synthase in submerged rice seedling indicates the important metabolic role of the glyoxylate cycle, Acta Biochim. Biophys., 37, 406-414, 2005.

Marin, F., Smith, M., Isa, Y., Muyzer, G., and Westbroek, P.: Skeletal matrices, muci, and the origin of invertebrate calcification, $\mathrm{P}$. Natl. Acad. Sci. USA, 93, 1554-1559, 1996.

Marshall, C. R.: Explaining the Cambrian "explosion" of animals, Annu. Rev. Earth Planet. Sci., 34, 355-84, 2006. 
Marubini F., Ferrier-Pages C., and Cuif J. P.: Suppression of growth in scleractinian corals by decreasing ambient carbonate ion concentration: a cross-family comparison, P. Roy. Soc. London Ser. B, 270, 179-184, 2003

McConnaughey, T.: ${ }^{13} \mathrm{C}$ and ${ }^{18} \mathrm{O}$ isotopic disequilibrium in biological carbonates: I. Patterns, Geochim. Cosmochim. Ac., 53, 151$162,1989$.

McConnaughey, T. A. and Whelan, J. F.: Calcification generates protons for nutrient and bicarbonate uptake, Earth Sci. Rev., 42, 95-117, 1997.

Meibom, A., Yurimoto, H., Cuif J. P., Domart-Coulon, I., Houlbreque, F., Constantz, B., Dauphin, Y, Tambutté, E., Tambutté, S., Allemand, D., Wooden, J., and Dunbar, R.: Vital effects in coral skeletal composition display strict three-dimensional control, Geophys. Res. Lett., 33, L11608, doi:10.1029/2006GL025968, 2006.

Mendes, J. M. and Woodley, J. D.: Effect of the 1995-1996 bleaching event on polyp tissue depth, growth, reproduction and skeletal band formation in Montastraea annularis, Mar. Ecol.-Prog. Ser., 235, 93-102, 2002.

Mizrachi, I., Loya, Y., Rosenfeld, M., Kramarski-Winter, E., Yam, R., and Shemesh, A.: The build up of the isotopic signal in skeletons of the stony coral Porites Lutea, Geochim. Cosmochim. Ac., 74, 7021-7030, 2010.

Montaggioni, L. F.: History of Indo-Pacific coral reef systems since the last glaciation: Development patterns and controlling factors, Earth Sci. Rev., 71, 1-75, 2005.

Muscatine, L., McCloskey, L. R., and Marian, R. E.: Estimating the daily contribution of carbon from zooxanthellae to coral animal respiration, Limnol. Oceanogr., 26, 601-611, 1981.

Muscatine, L., Porter, J. W., and Kaplan, I. R.: Resource partitioning by reef corals as determined from stable isotope composition: I. $\delta^{13} \mathrm{C}$ of zooxanthellae and animal tissue vs. depth, Mar. Biol., 100, 185-193, 1989.

Mutaftschiev, B.: Nucleation, in: Handbook on Crystal Growth, edited by: Hurle, D. T. J., Amsterdam, 187-248, 1993.

Nakamura, T. and van Woesik, R.: Differential survival of corals during the 1998-bleaching event is partially explained by waterflow rates and passive diffusion, Mar. Ecol.-Progr. Ser., 212, 301304, 2001

Ogilvie, M. M.: Microscopic and systematic study of Madreporarian types of corals, Philos. T. Roy. Soc. B., 187, 83-345, 1896.

Oliver, J. K.: Intra-colony variation in the growth of Acropora formosa: extension rates and skeletal structure of white (zooxanthellae-free) and brown-tipped branches, Coral Reefs, 3, 139-147, 1984.

Oliver, J. K.: Recurrent seasonal bleaching and mortality of corals on the Great Barrier Reef, Proc. 5th Int. Coral Reef Symp., 4, 201-206, 1985.

Patterson, M. R., Sebens, K. P., and Olson, R. R.: In situ measurements of flow effects on primary production and dark respiration in reef corals, Limnol. Oceanogr., 36, 936-948, 1991.

Pearse, V. B.: Sources of carbon in the skeleton of the coral Fungia scutaria, in: Experimental Coelenterate Biology, edited by: Lenhoff, H. M. and Muscatine, L., Univ. of Hawaii Press, Honolulu, 239-245, 1971.

Pennisi, E.: Sea anemone provides a new view of animal evolution, Science, 317, 27, 2007.
Peterson, K. J., McPeek, M. A., and Evans, D. A. A.: Tempo and mode of early animal evolution: inference from rocks, Hox, and molecular clocks, Paleobiology., 31, 36-55, 2005.

Porter, J. W., Fitt, W. K., Spero, H. J., Rogers, C. S., and White, M. W.: Bleaching in reef corals: physiological and stable isotopic responses, P. Natl. Acad. Sci. USA, 86, 9342-9346, 1989.

Pörtner, H. O.: Oxygen- and capacity-limitation of thermal tolerance: a matrix for integrating climate-related stressor effects in marine ecosystems, J. Exp. Biol., 213, 881-893, 2010.

Pueschel, C. M.: Calcium oxalate crystals in the green alga Spirogyra sp. (Zygnematales, Chlorophyta), J. Phycol., 36, 55-56, 2000.

Pueschel, C. M. and West, J. A.: Calcium oxalate crystals in the marine red alga Spyridia filamentosa (Ceramiales; Rhodophyta), Phycologia, 46, 565-571, 2007.

Rands, M. L., Douglas, A. E., Loughman, B. C., and Ratcliffe, R. G.: Avoidance of hypoxia in a cnidarians symbiosis by algal photosynthetic oxygen, Biol. Bull., 182, 159-162, 1992.

Raz-Bahat, M., Erez, J., and Rinkevich, B.: In vivo lightmicroscopic documentation for primary calcification processes in the hermatypic coral Stylophora pistillata, Cell Tissue Res., 325, 361-368, 2006.

Rodolfo-Metalpa, R., Martin, S., Ferrier-Pagès, C., and Gattuso, J.-P.: Response of the temperate coral Cladocora caespitosa to mid- and long-term exposure to $\mathrm{pCO}_{2}$ and temperature levels projected for the year $2100 \mathrm{AD}$, Biogeosciences, 7, 289-300, doi:10.5194/bg-7-289-2010, 2010.

Rodriguez-Lanetty, M., Scaramuzzi C., Quinnell R. G., and Larkum, A. W. D.: Transport of symbiotic zooxanthellae in mesogleal canals of Zoanthus robustus? Coral Reefs, 24, 195196, 2005.

Rotmann, S.: Tissue thickness as a tool to monitor the stress response of massive Porites corals to turbidity impact on Lihir Island, Papua New Guinea, Ph.D. thesis, James Cook Univ., 2004.

Rollion-Bard, C., Chaussidon, M., and France-Lanord, C.: pH control on oxygen isotopic composition of symbiotic corals, Earth Planet. Sci. Lett., 215, 275-288, 2003a.

Rollion-Bard, C., Blamart, D., Cuif J. P., and Juillet-Leclerc, A.: Microanalysis of $\mathrm{C}$ and $\mathrm{O}$ isotopes of azooxanthellate and zooxanthellate corals by ion microprobe, Coral Reefs, 22, 405-415, 2003 b.

Rollion-Bard, C., Blamart, D., Cuif, J. P., and Dauphin, Y.: In situ measurements of oxygen isotopic composition in deep-sea coral, Lophelia pertusa: Re-examination of the current geochemical models of biomineralisation, Geochim. Cosmochim. Ac., 74, 1338-1349, 2010.

Scoffin, T. P., Tudhope, A. W., Brown, B. E., Chansang, H., and Cheeney, R. F.: Patterns and possible environmental controls of skeletogenesis of Porites lutea, South Thailand, Coral Reefs 11, 1-11, 1992.

Sebens, K. P. and Done, T. J.: Water flow, growth form and distribution of scleractinian corals: Davies Reef (GBR), Australia, Proc. 7th Int. Coral Reef Symp., 1, 557-568, 1992.

Schnarrenberger, C. and Martin, W.: Evolution of the enzymes of the citric acid cycle and the glyoxylate cycle of higher plants: a case study of endosymbiotic gene transfer, Eur. J. Biochem., 269, 868-883, 2002.

Singh, K., Deonarine, D., Shanmugam, V., Senger, D. R., Mukherjee, A. B., Chang, P-L., Prince, C. W., and Mukherjee, B. B.: 
Calcium-binding properties of Osteopontin derived from nonosteogenic sources, J. Biochem., 114, 702-707, 1993.

Stafford-Smith, M. G.: Sediment-rejection efficiency of 22 species of Australian scleractinian corals, Mar. Biol., 115, 229-243, 1993.

Stanley, G. D.: Photosymbiosis and the evolution of modern coral reefs, Science, 312, 857-858, 2006.

Stolarski, J.: Three-dimensional micro- and nanostructural characteristics of scleractinian coral skeleton: a biocalcification proxy, Acta Palaeontol. Pol., 48, 497-530, 2003.

Suzuki, A., Hibino, K., Iwase, A., and Kawahata, H.: Intercolony variability of skeletal oxygen and carbon isotope signatures of cultured Porites corals: Temperature-controlled experiments, Geochim. Cosmochim. Ac., 69, 4453-4462, 2005.

Tambutté, É., Allemand D., Mueller E., and Jaubert, J.: A compartmental approach to the mechanism of calcification in hermatypic corals, J. Exp. Biol., 199, 1029-1041, 1996.

Tanzil, J. T. I., Brown, B. E., Tudhope, A. W., and Dunne, R. P.: Decline in skeletal growth of the coral Porites lutea from the Andaman Sea, South Thailand between 1984 and 2005, Coral Reefs, 28, 519-528, 2009.

True, J. D.: Massive Porites corals as indicators of environmental change, Ph. D. thesis, James Cook Univ., 2005.

Vago, R., Gill, E., and Collingwood, J. C.: Laser measurements of coral growth, Nature, 386, 30-31, 1997.

Veron, J. E. N. and Pichon, M.: Scleractinia of eastern Australia Part 1, In: Australian Institute of Marine Science Monograph Series Vol. 1., Australian Government Publishing Service, Canberra, 1976.

Vize, P.: Transcriptome analysis of the circadian regulatory network in the coral Acropora millepora, Biol. Bull., 2, 131-137, 2009.
Weber, J. N. and Woodhead, P. M. J.: C and O isotope fractionation in the skeletal carbonate of reef-building corals, Chem. Geol., 6, 93-117, 1970.

Wei, G., McCulloch, M. T., Mortimer, G., Deng, W., and Xie, L.: Evidence for ocean acidification in the Great Barrier Reef of Australia, Geochim. Cosmochim. Ac., 73, 2332-2346, 2009.

Willmer, P., Stone, G., and Johnston, I.: Environmental physiology of animals, Blackwell, Oxford, 2000.

Wooldridge, S. A.: A new conceptual model for the warm-water breakdown of the coral-algae endosymbiosis, Mar. Freshwater Res., 60, 483-496, 2009a.

Wooldridge, S. A.: Water quality and coral bleaching thresholds: Formalising the linkage for the inshore reefs of the Great Barrier Reef, Australia, Mar. Pollut. Bull., 58, 745-751, 2009b.

Wooldridge, S. A.: Is the coral-algae symbiosis really mutuallybeneficial for the partners?, BioEssays, 32, 615-625, 2010.

Wooldridge, S. A.: A hypothesis linking sub-optimal seawater $p \mathrm{CO}_{2}$ conditions for cnidarian-Symbiodinium symbioses with the exceedence of the interglacial threshold (> $260 \mathrm{ppmv}$ ), Biogeosciences, 9, 1709-1723, doi:10.5194/bg-9-1709-2012, 2012.

Yellowlees, D., Rees, T. A., and Leggat, W.: Metabolic interactions between algal symbionts and invertebrate hosts, Plant Cell Environ., 31, 679-694, 2008.

Yonge, C. M., Yonge, M. J., and Nicholls, A. G.: Studies of the physiology of corals VI. The relationship between respiration in corals and the production of oxygen by their zooxanthellae, Sci. Rep. Great Barrier Reef Exp. 1928-29, 1, 213-251, 1932.

Yu, L., Jiang, J., Zhang, C., Jiang, L., Ye, N., Lu, Y., Yang, G., Liu, E., Peng, C., He, Z., and Peng, X.: Glyoxylate rather than ascorbate is an efficient precursor for oxalate biosynthesis in rice, J. Exp. Bot., 61, 1625-1634, 2010. 